GEOLOGICAL SURVEY CIRCULAR 616

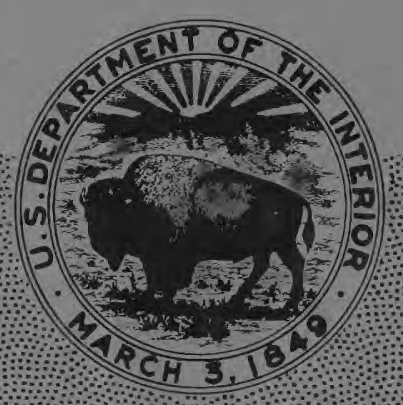

Sensor Detection

Capabilities Study 



\section{Sensor Detection Capabilities Study}

By John E. Wilson

\section{GEOLOGICAL SURVEY CIRCULAR 616}

Interagency Report NASA-143

Prepared by the U.S. Geological Survey for

the National Aeronautics and Space Administration

under contract No. W-12570, task No. 160-75-01-31-10

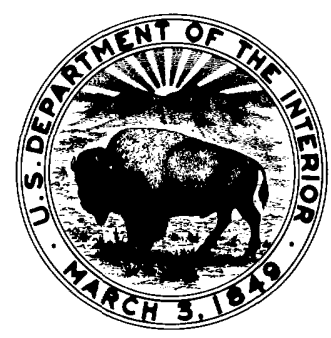


United States Department of the Interior

WALTER J. HICKEL, Secretary

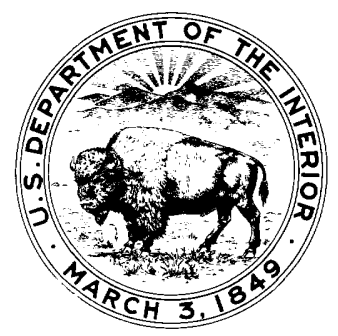

Geological Survey

William T. Pecora, Director

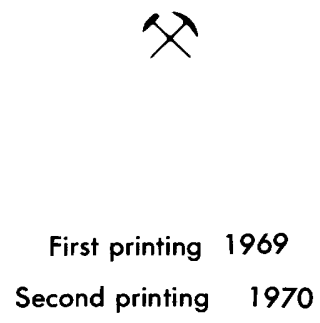

Free on application to the U.S. Geological Survey, Washington, D.C. 20242 
Page

Introduction and rationale

Methodology -

Internal accuracy determination

Summary of results

Selected references -

\title{
ILLUSTRATIONS
}

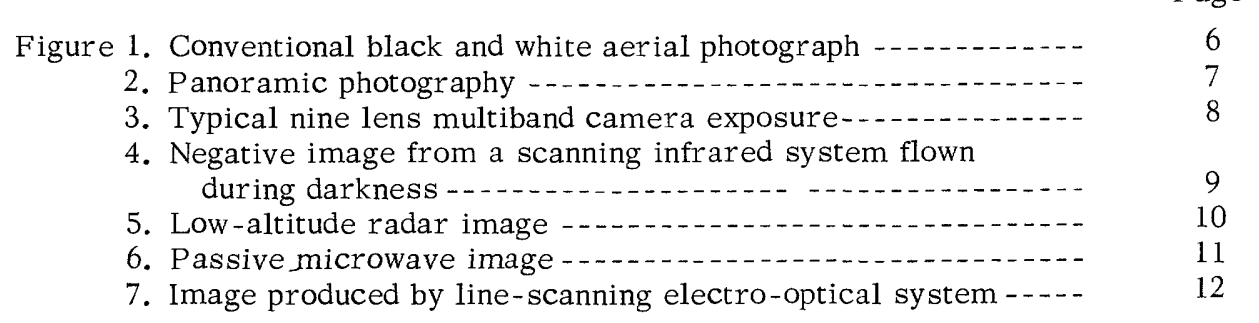

TABLES

Airfields -..-1-2

Page

Archeological sites- .

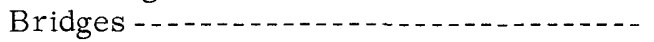

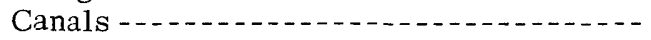

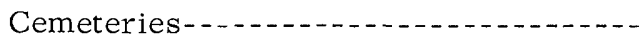

Crops--

Dams - . - .

Drainage systems -................

Earthquake areas _.........................

Estuarine studies -...-_...

Fills-_-_. -

Fires - .

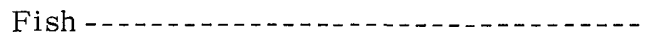

Flood areas -.........

Flood plains -..............

Forests -...........

Gross geologic structures-_...-...--

Ice -. -

Irrigation networks

14 High-voltage lines-_........ 18

15 Hot springs- 19

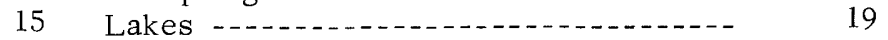

14 Land use -........ 19

14 Low-voltage lines -.......... 18

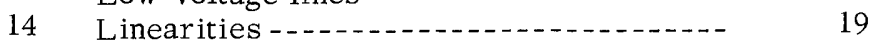

15 Minerals exploration _............. 19

16 Mining -............ 19

16 Outcroppings -........ 19

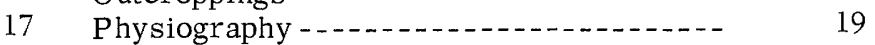

17 Pipelines-a 20

17 Petroleum exploration-.......... 20

17 Pollution, air - 16

16 Pollution, land -.......... 21

16 Pollution, water $16 \ldots$

16 Power generation -............. 20

17 Quarries -.................................. 21

17 Radio transmitters -

18 Railroads _............................. 21 
Rangelands -

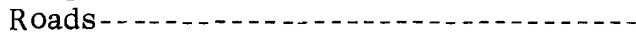

Rock types -..-

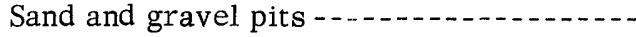

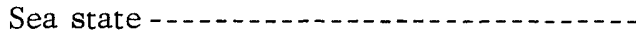

Sewage processing -....

Shorelines-...........

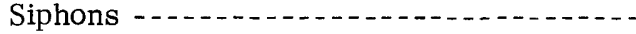

Snow pack
Page

Page

22

Soil- -

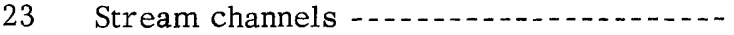

22 Storm effects -...-.......

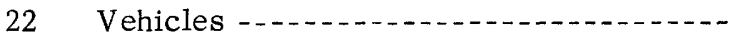

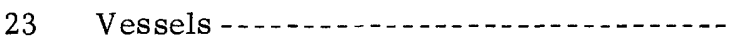

23 Wakes

23 Water-......

23

23

Wells -.................................. 


\title{
Sensor Detection Capabilities Study
}

\author{
By John E. Wilson
}

\section{INTRODUCTION AND RATIONALE}

The present state of remote sensing technology is the result of a large num be $r$ of investigations concerning the use of both imaging and nonimaging sensor devices to detect and analyze various phenomena. This report summarizes results of a study in which 10 of those sensors were investigated and rated on their effectiveness in identifying characteristics of 98 earth resources targets.

Other investigations have not previously been correlated in a single document to summarize the relative capabilities of each sensor, applied to specific ground targets. In this study, the capabilities of each sensor have been listed and rated, in decreasing order of effectiveness from 1 to 8 , through comparative analysis of sensor records. A project may require the use of one or more remote sensing devices, and the earth scientist is then confronted with the problem of instrument selection. Four major variables which affect the selection of an appropriate sensor are:

1. Target and background identity.

2. Sensor availablility.

3. Sensor capabilities and characteristics.

4. Data collection system economics.

Other variables are:

1. Time of day.

2. Longitude.

3. Cloud cover.

4. Precipitation.

5. Dust, smoke, fog.

6. "Look" angle.

7. Sun angle.

8. Weather history.

Consequently, the e a r th scientist with only a basic knowledge of remote sensing is confused by the detail required to make a confident selection of a system for a given research program.

\section{METHODOLOGY}

A list of earth science targets was first proposed, sufficient in number to allow for study depth and diversity, while maintaining a manageable num ber of indicator objects to satisfy the different users of those sensing devices. That list was submitted to Geological Survey personnel for study, additions, and deletions, and the modified list was accepted for project use. A mission was then evolved with multiple flightlines to provide sensor records for a majority of the listed objects. The flight mission (NASA Mission 73) utilized sensing devices that spanned a significant part of the electromagnetic spectrum from ultraviolet th $\mathrm{roug} h$ airborne radar, and sensor redundance was provided whenever possible.

From the resultant images and signals, data sets were compiled. These sets, one for each target, normally consisted of one or more presentations of that target with representative data from each sensor. In addition to analyzing these data, a library search was made, and several Government agencies were visited, to view other pertinent multisensor images. Sensor records that were viewed and rated included:

1. Black and white photography.

2. Color photography.

3. Infrared (IR) color photography.

4. Black and white infrared photography.

5. 2- to 4-micron thermal infrared imagery.

6. 8- to 14-micron thermal infrared imagery.

7. Side-looking radar (SLAR) imagery.

8. Electro-optical (television) imagery.

9. Imaging microwave imagery.

10. Nonimaging scatterometer data.

Black and white photography as rated here includes multiband photography. Such photographic and electrooptical devices are evaluated as if the optimum filter for a given task was used. 
The selection of the most appropriate airborne or spaceborne device for a given survey has become progressively more difficult with the development and (or) improvement of sensor systems. In past years, this selection was restricted to an airborne camera and panchromatic film. Present technology poses a choice among many instruments. Some of the newer sensors do not form an image but return an electric signal which variés in amplitude as changes in the target are encountered. All of the electromagnetic sensors record object reflectance, absorption, or $\mathrm{radi}$ ation in wavelengths from 400 millimicrons to nearly 1.5 centimeters. Representative imagery produced by these sensors is shown in figures 1 thrcugh 7 .

The quality determinations set forth in this report are subjective and are based on images derived from aircraft mounted sensors. Where a sensor is not rated, no capability is presumed to exist. The ranking of sensors by a succession of numbers does not imply that the higher rated sensors will accomplish any given detection task with precision and quality. The ratings are strictly relative; the detection capabilities of one sensor system are compared with another for each individual target.

No consideration is given here to those variables which affect sensor performance. Instead, performance ratings are based on the supposed optimum conditions existing at the time e a ch target.is sensed. Camouflage caused by rain, fog, and clouds can change detection probabilities, and the probability and direction of such changes should be considered in sen s or selection.

The attached evaluation sheets are arranged in alphabetical order of the selected targets. The numbers represent the order of capability for the rated sensor to function successfully in detecting and identifying the target object under study. Where no capability order is shown, no detection-recognition capability exists at present.

Because this report concludes that photographs of one type or another offer the greater remote sensing capability in most instances, it would appear appropriate to define the camera systems utilized. Performance evaluations are for low altitude (daylight), high altitude (daylight), and low altitude (night) conditions. Low altitude is presumed to include altitudes between 1,000 and 5,000 feet, while high altitude is based on a presumed altitude anywhere between 10 miles and 100 miles. Night data are given only for a presumed low altitude platform since no currently available infrared set or radar systems would yield useful data from orbital or extreme flight altitudes on targets under consideration in this report.

All low altitude evaluations are based on high quality, commercially available framing cameras, while the high altitude (or satellite) platform envisions the use of a hypothetical system capable of a 10-foot ground resolution. The practicality of such ground resolution has been extrapolated from performances achieved by use of commercially available components at far lower altitudes.

\section{INTERNAL ACCURACY DETERMINATION}

Performance data for all of the sensor-target combinations were assembled in a matrix. The matrix was then reviewed for internal contradictions. When such contradictions were found, target and sensor relationships and characteristics were reviewed; new performance judgments were derived when indicated; and the new data were examined in the framework of the accuracy matrix.

\section{SUMMARY OF RESULTS}

Of the 98 targets considered in this evaluation, 89 indicated that a photographic system held the greatest promise of object detection. Infrared, side-looking radar, scatterometer, and passive microwave each were capable of significant contributions over one or more of the listed targets.

Sensor evaluation indicated little spaceborne capability for extant devices other than photography. This is not to be construed as a condemnation of such sensors; rather, it reflects the need for continuing sensor improvement and continued investigation into the uses of "as is" imagery.

\section{SELECTED REFERENCES}

Beatty, F. D., Beccasio, A. D., Becker, E. S., Brodie, R. A., Holmes, R. F., Simons, J. H., and Powers, Richard, 1965, Geoscience potentials of sidelooking radar: Alexandria, Va., Autometric Facility, Raytheon Corp., 90 p.

Cameron, H. L., 1961, Interpretation of high altitude small-scale photography: Canadian Surveyor, v. 15, no. 10 , p. 567-573.

Cantrell, J. L., 1964, Infrared geology: Photogramm. Eng., v. 30, no. 6, p. 916-941.

Chow, V. T., ed., 1954, Handbook of applied hydrology: New York, McGraw-Hill Book Co., 29 sec.

Cronin, J. F., 1967, Terrestrial multispectral photography: Cambridge, Mass., U.S. Air Force Cambridge Research Lab., Spec. Rept. 56.

Dellwig, L. F., and Moore, R. K., 1966, The Geological value of simultaneously p roduced like- and cross-polarized radar imagery: Jour. Geophys. Research, v. 71, No. 14, p. 3597-3601.

Hannah, L. D., and others, 1964, The Experimental evaluation of multisensor intelligence s y s tem s: Pittsburgh, Pa., Am. Inst. for Research, Tech. Doc. Rept. $-64-160,137 \mathrm{p}$.

Holmes, R. F., and Footen, J. J., 1968, Selected bibliography of the terrain sciences: Alexandria, Va., Autometric Facility, Raytheon Corp., 39 p.

Holter, D. E., 1963, Contrast enhancement of military targets by spectral filtering: Redstone A r s enal, Ala., U.S. Army Missile Command, Rept. TR 63-3, $32 \mathrm{p}$.

International Business Machines Corporation, 1968, Sensor definition study: Bethesda, Md., Internat. Business Machines Corp., 145 p., App. I, 188p.

Landen, David, 1963, Photo interpretation of ice and snow features in Antarctica: Symposium on photo 
interpretation, Delft, Netherlands 1963, Proc. v. 14 , p. 367-373.

Morain, S. A., and Simonett, D. S., 1967, K-band radar in vegetation mapping: Photogramm. Eng., v. 33, no. 7, p. 730 .

Polytechnical Institute of Brooklyn, 1965, The Microwave Institute programs: New York, B rooklyn Polytech. Inst., Rept. R-452.27.65, 143 p.

Rome Air Development Center, 1963, Optimized coherent optical receiver techniques: Rome, N. Y., Rome Air Devel. Center, Tech. Rept. TDR-63-490, $22 \mathrm{p}$.

1963, R apid identification and interpretation techniques: Rome, N. Y., Rome Air Devel. Center, Rept. TDR-63-421, 107 p.

1965, The Compilation of representative sensor imagery: Rome, N. Y., Rome Air Devel. Center, Rept. TR-64-555, $51 \mathrm{p}$.

Simpson, R. B., 1966, Radar as a ge og raph i c tool: Assoc. Am. Geographers Annals, v. 56, no. 1, p. $80-96$.

Sridas, S., 1966, Interpretation and mapping of rural land from air photographs in Ceylon: Photogrammetria, v. 21 , no. 3 , p. 77-82.
Theurer, Charles, 1969, Color and infrared experimental photography for coastal mapping, Photogramm. Eng., v. 25, no. 4, p. 565-569.

U.S. Army Corps of Engineers, 1965, Earth Resources Surveys from Spacecraft: Ft. Belvoir, Va., U.S. Army Corps. of Engineers, prepared for Natl. Aeronautics and Space Adm., 2 v.

Van Steenburgh, R. P., 1963, Flight evaluation of the RCA image amplifier camera for night aerial reconnaissance: Long Island City, N. Y., Aeroflex Labs., Inc., Rept. ASD-TDR 62-992, 62 p.

Walters, R. L., 1968, Radar bibliog raphy for geoscientists: Lawrence, Kansas Univ. Center for Research, Rept. 61-30, 28 p.

Whittenburg, J. A., 1964, E f f e ct s of target-ground parameters on target identification: Human F actors Research and Development, 10 Ann. Conf., Oct. 1964, Proc., p. 101-109.

Wilburn, D. K., 1965, Spectra notebook volume I, Material, targets, and background data: U.S. A rmy Tank Automotive Center, Tech. Rept. 8863, 63 p.

Wobber, F. J., 1968, Environmental studies using Gemini photography: Bethesda, Md., Internat. Business Machines Corp., Tech. Rept. 48-68-002. 

FIGURES 1-7 


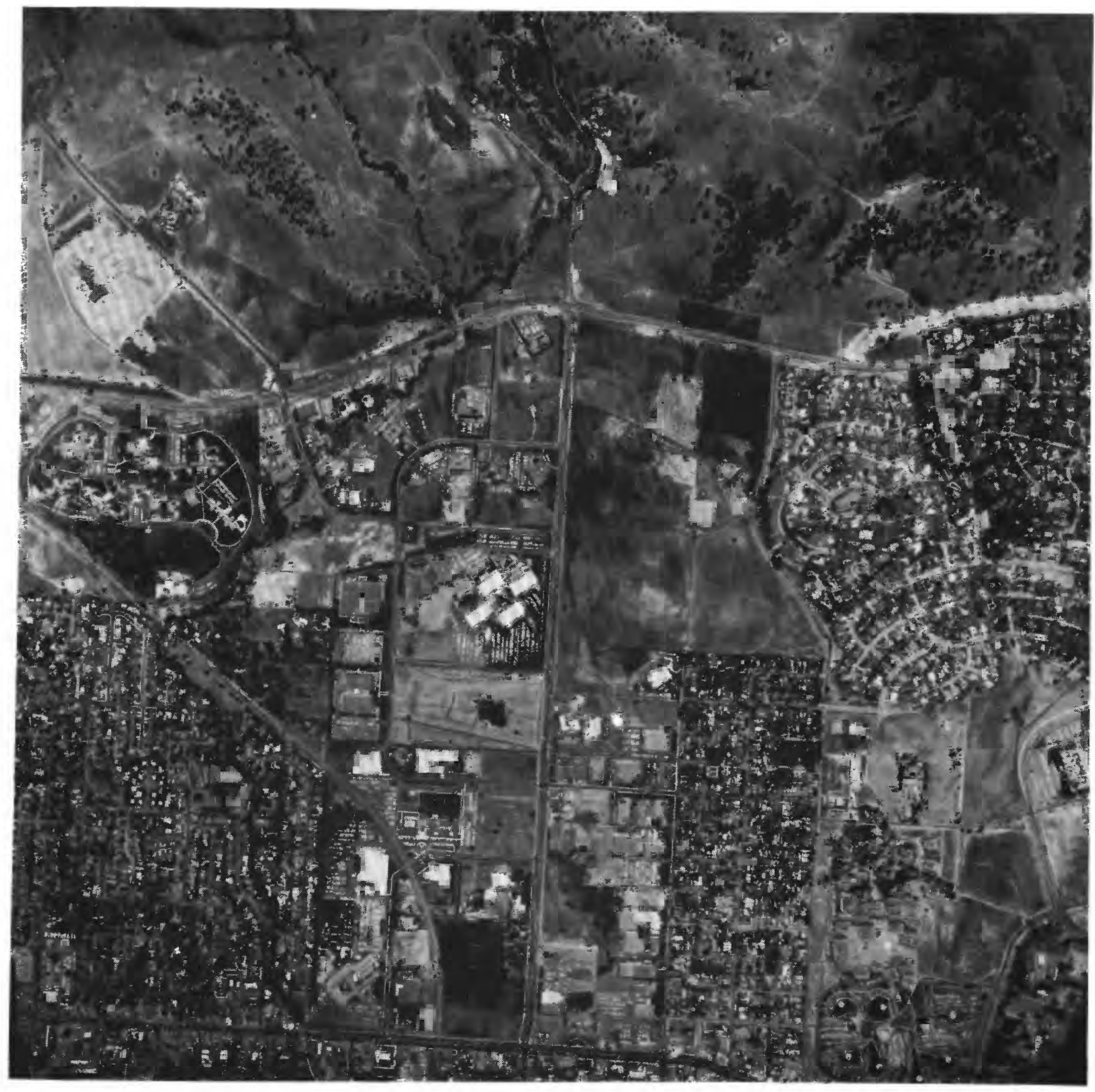

Figure 1.-A conventional black and white aerial photograph. Such photography can have higl. geometric fidelity. 

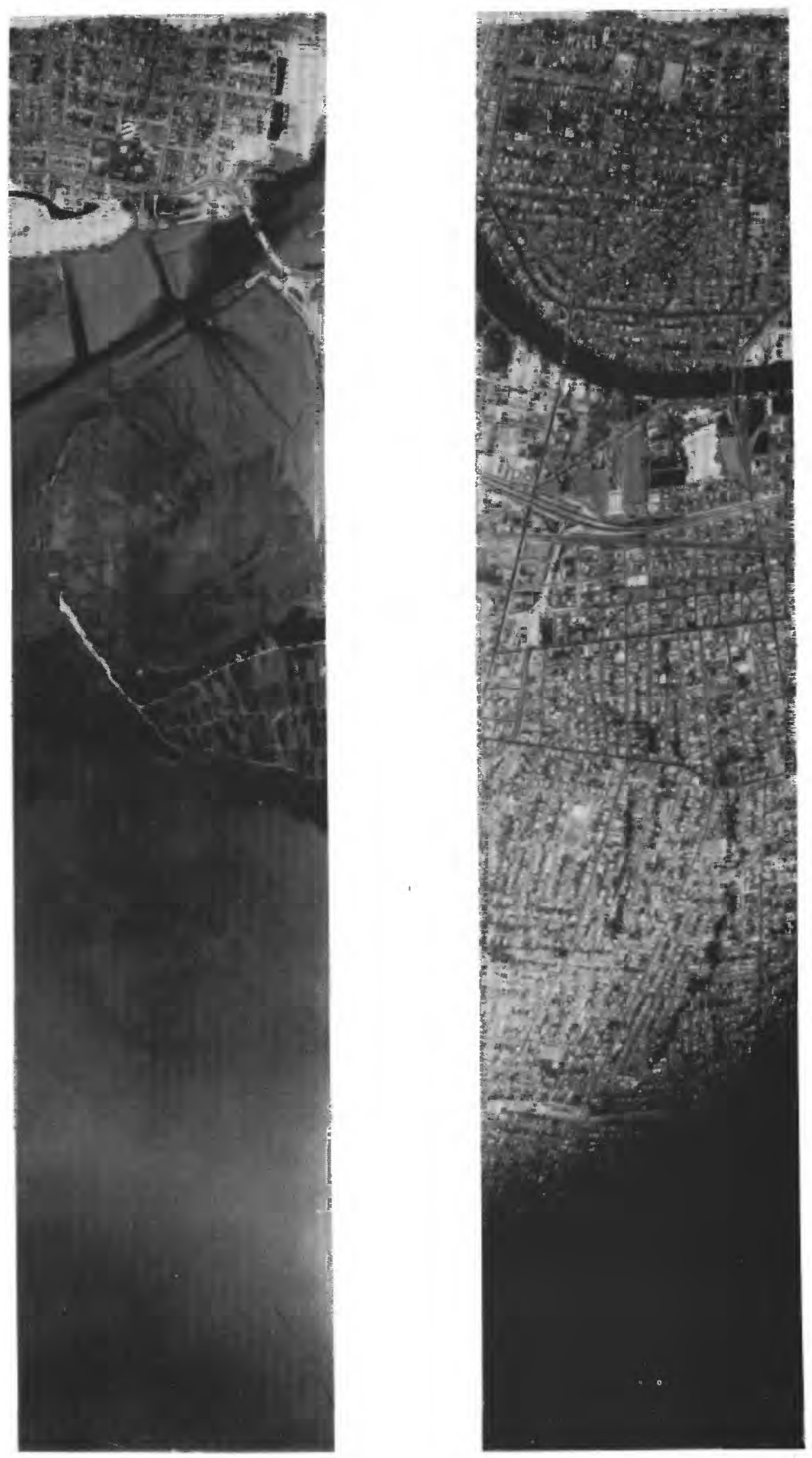

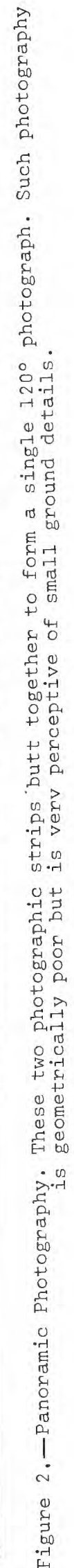



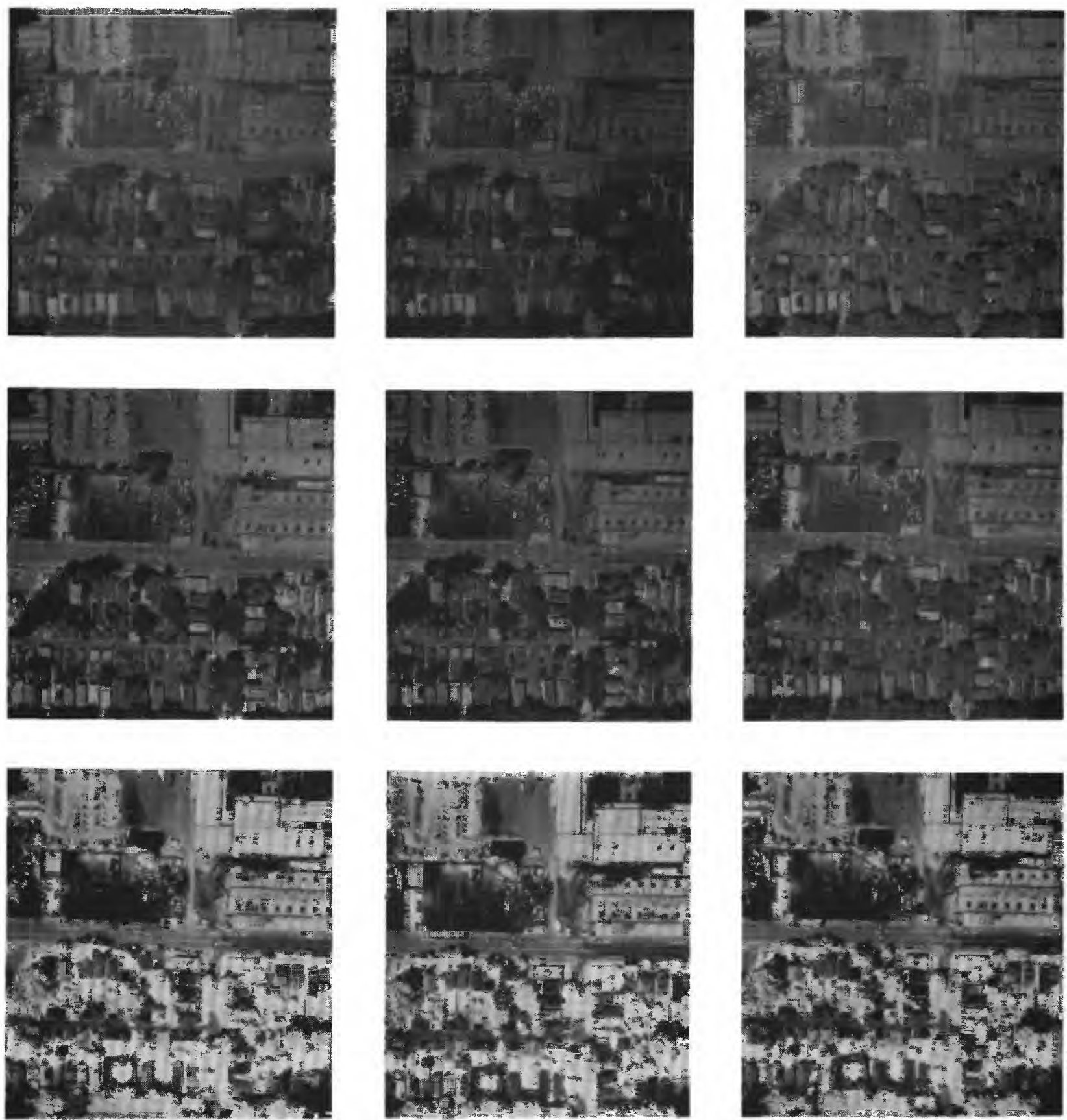

Figure 3.-A typical nine lens multiband camera exposure. Object density differences in the nine selectively filtered photographs can aid in object recognition. 


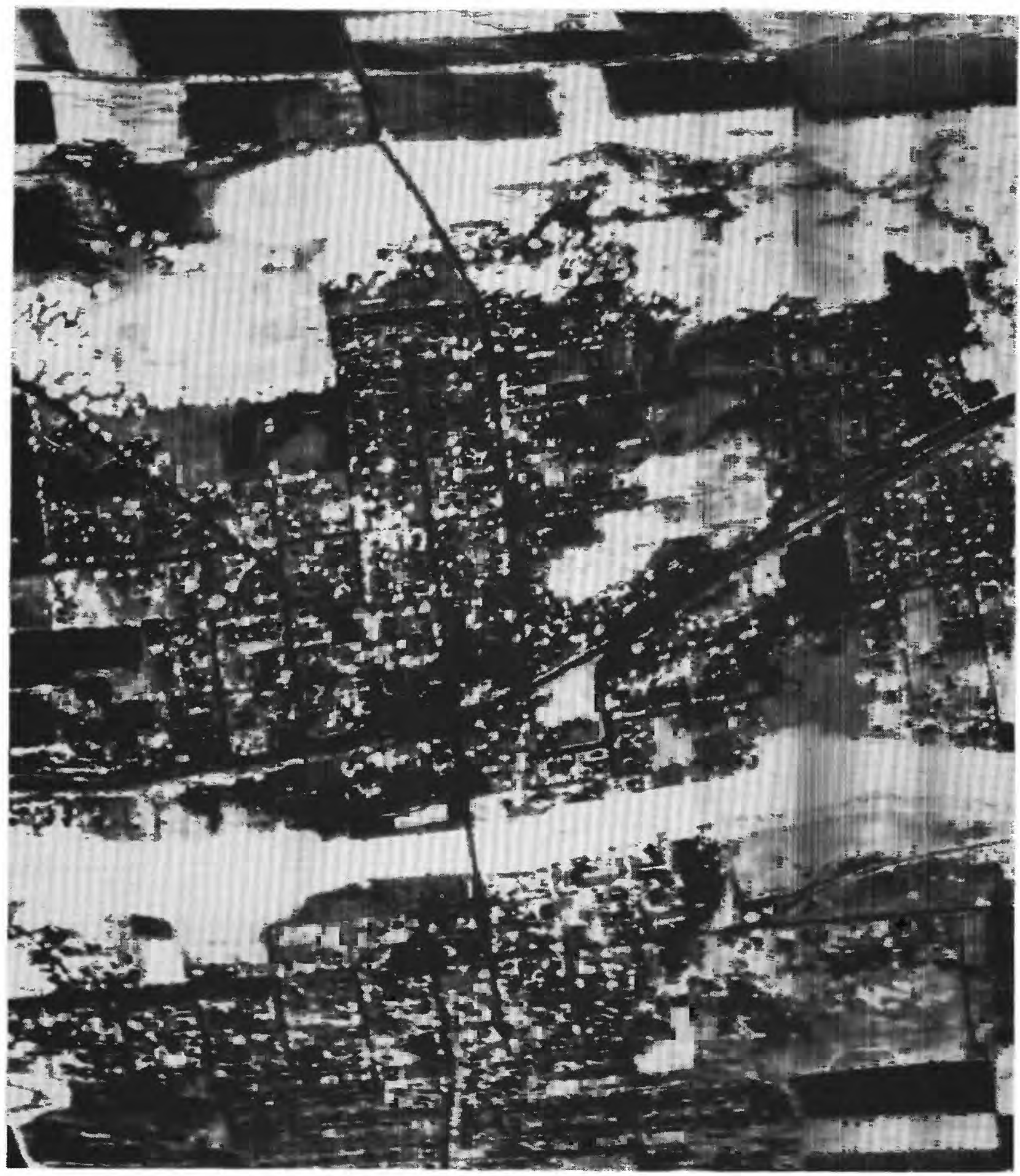

Figure 4.-A negative image from a scanning infrared system flown during darkness. A cold river in the foreground and cold swamplands at the top are both displayed here as white. 


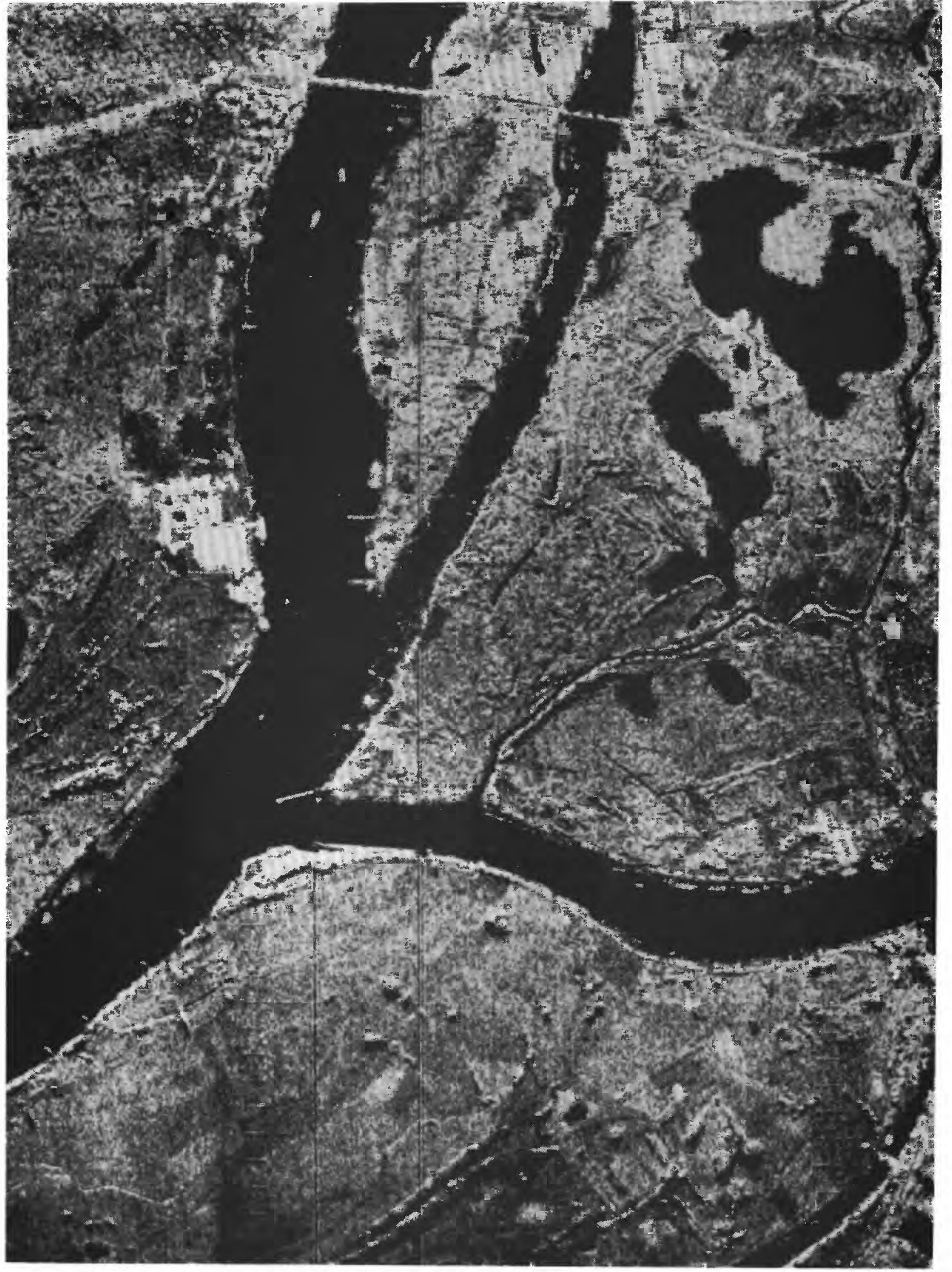

Figure 5.-This low-altitude radar image of Portland, Oreg., displays the system's inability to provide information on any but very large objects. 


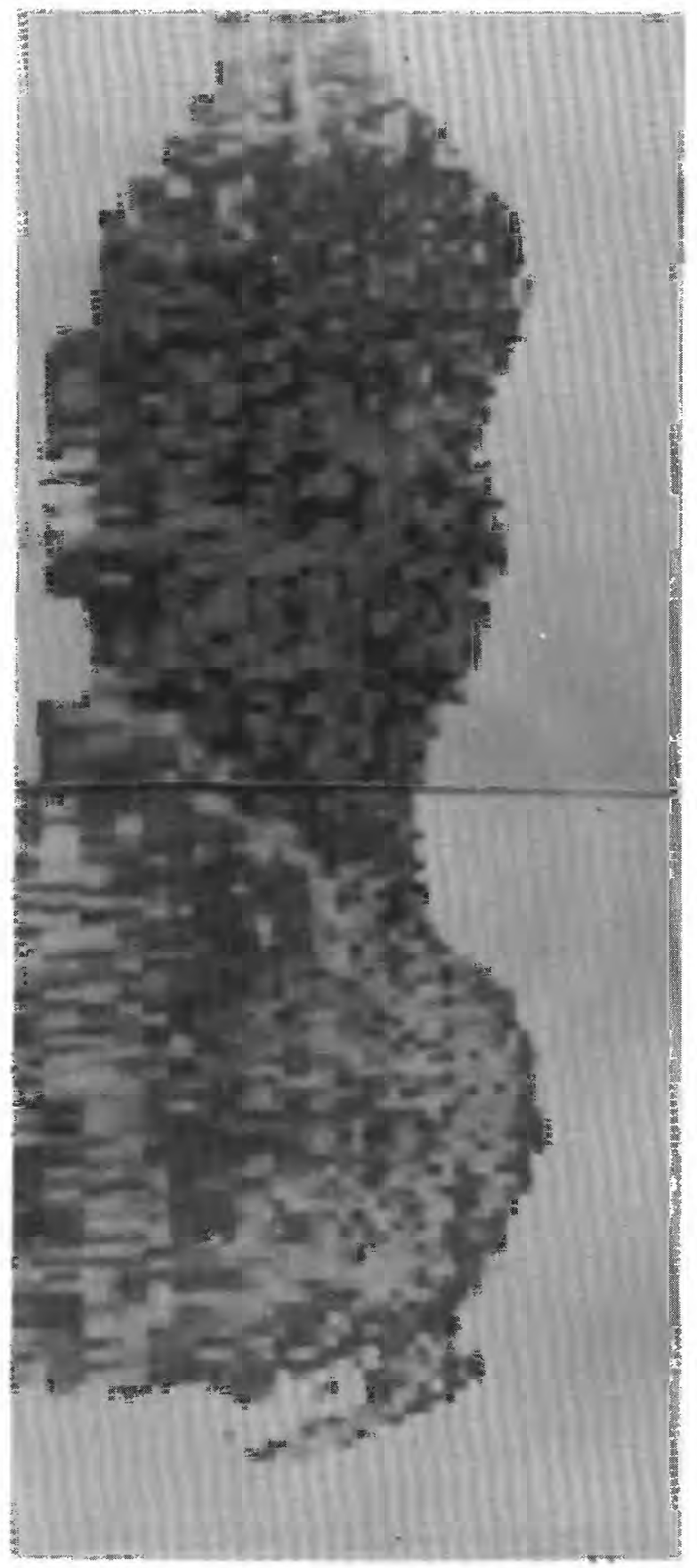

Figure 6.-Imaging passive microwave displays various surface temperatures of the Salton Sea as changing levels of gray. 


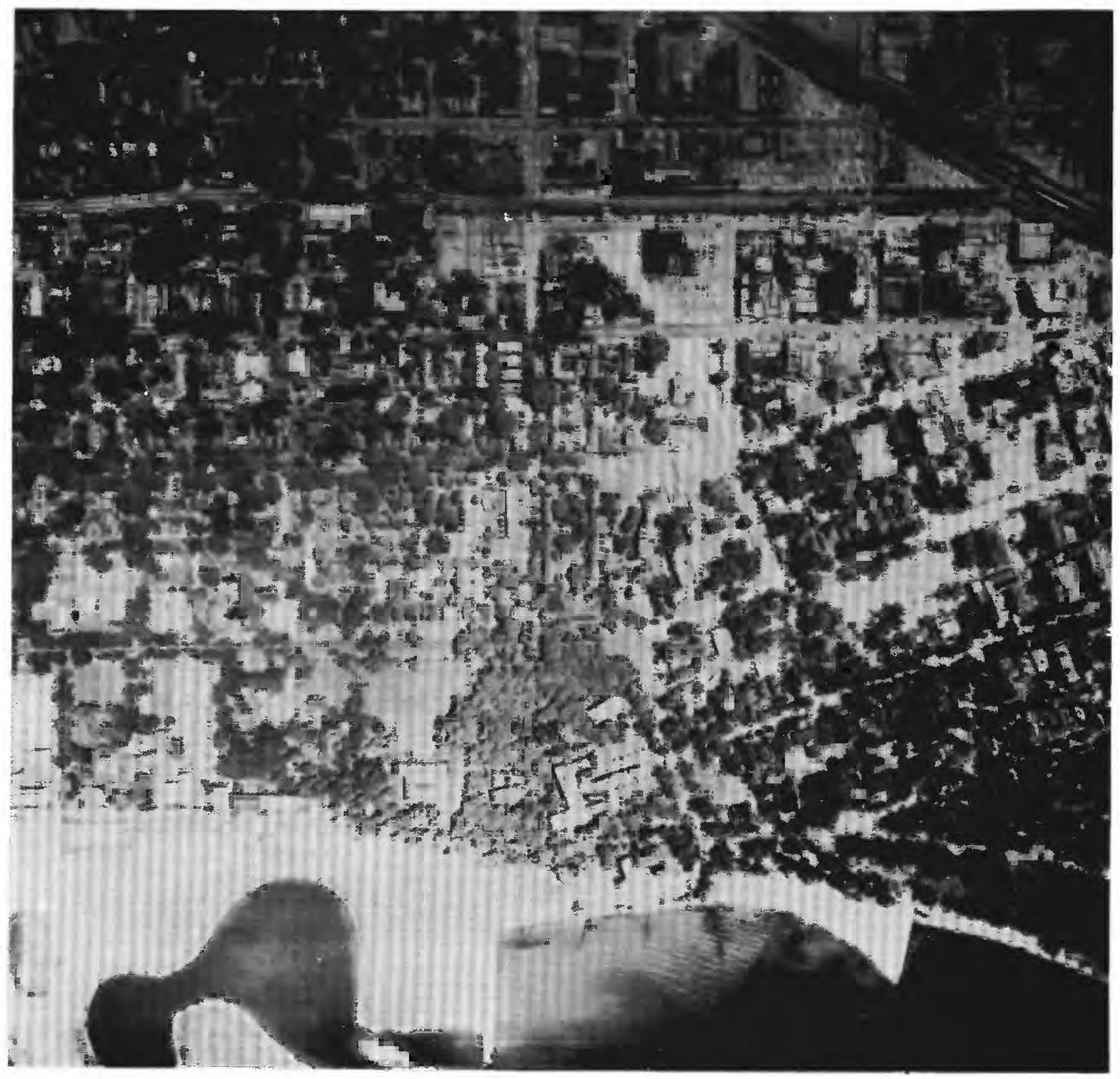

Figure 7.-This image was produced by a line scanning electro-optical system. The resultant quality is very close to that of a conventional camera system. 
[Ground resolution requirements are given in and night) are between 1,000 and 5,000 feet; miles. The numerical ranking of sensors is in highest rank (I) does not imply precision and

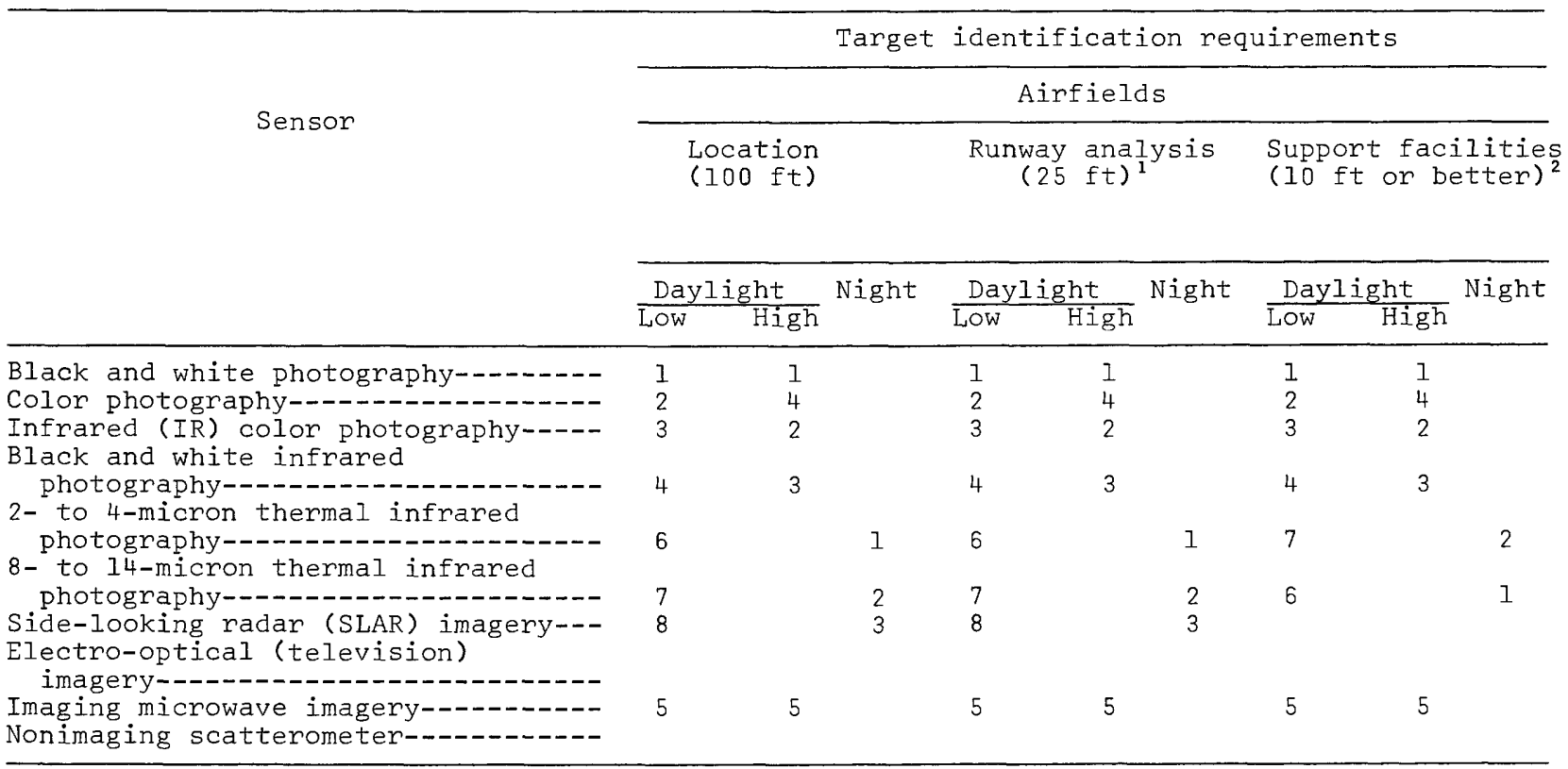
${ }^{1}$ Length, bearing, and taxiway
pattern.

\footnotetext{
${ }^{2}$ Hangars, POL storage, parking aprons, and control facilities.
}

\begin{tabular}{|c|c|c|c|c|c|c|c|c|c|}
\hline \multirow{4}{*}{ Sensor } & \multicolumn{9}{|c|}{ Target identification requirements-Continued } \\
\hline & \multicolumn{2}{|c|}{$\begin{array}{l}\text { Canals } \\
\text { (absorption } \\
\text { shape) }\end{array}$} & and & \multicolumn{3}{|c|}{$\begin{array}{l}\text { Cemeteries } \\
\text { (total area, veg- } \\
\text { tation, and } \\
\text { road network) }\end{array}$} & \multicolumn{3}{|c|}{ Crops } \\
\hline & Day & & Night & Day & & Night & \multicolumn{2}{|c|}{ Daylight } & \multirow[t]{2}{*}{ Night } \\
\hline & Low & High & & LOW & $\mathrm{High}$ & & LOW & High & \\
\hline Black and white photography------.- & 2 & 1 & & 3 & 1 & & 2 & 1 & \\
\hline Color photography-n-- & 4 & 4 & & 2 & 4 & & 4 & 4 & \\
\hline $\begin{array}{l}\text { Infrared (IR) color photography----- } \\
\text { Black and white infrared }\end{array}$ & 1 & 2 & & 1 & 2 & & 1 & 2 & \\
\hline $\begin{array}{l}\text { photography- } \\
\text { 2- to 4-micron thermal infrared }\end{array}$ & 3 & 3 & & 4 & 3 & & 3 & 3 & \\
\hline $\begin{array}{l}\text { Imaging microwave imagery } \\
\text { Nonimaging scatterometer }\end{array}$ & 5 & 5 & & 5 & 5 & & 5 & 5 & \\
\hline
\end{tabular}


parentheses. Low altitude evaluations (daylight

high altitude (daylight only), between 10 and 100

decreasing order of effectiveness, but even the optimum quality]

Target identification requirements-Continued.

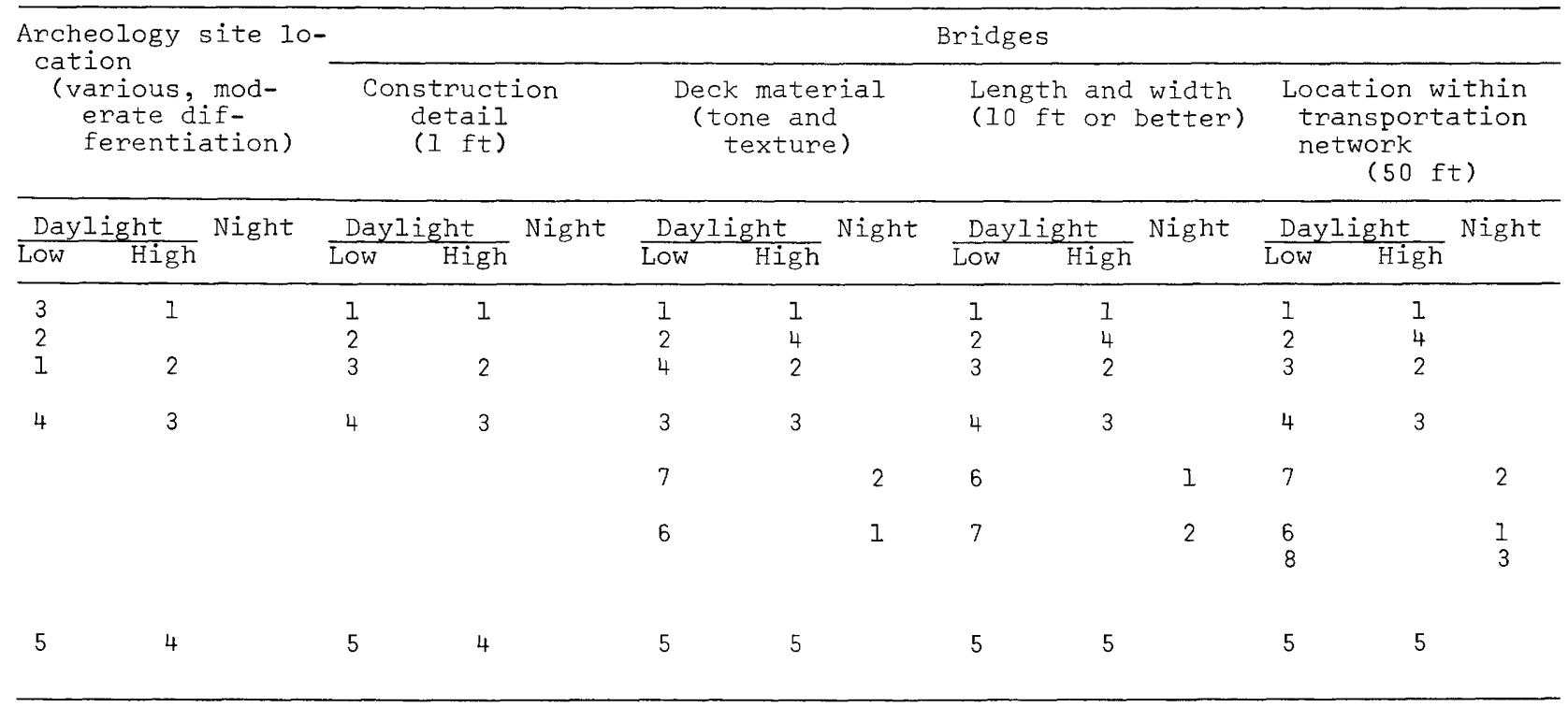

Target identification requirements-Continued

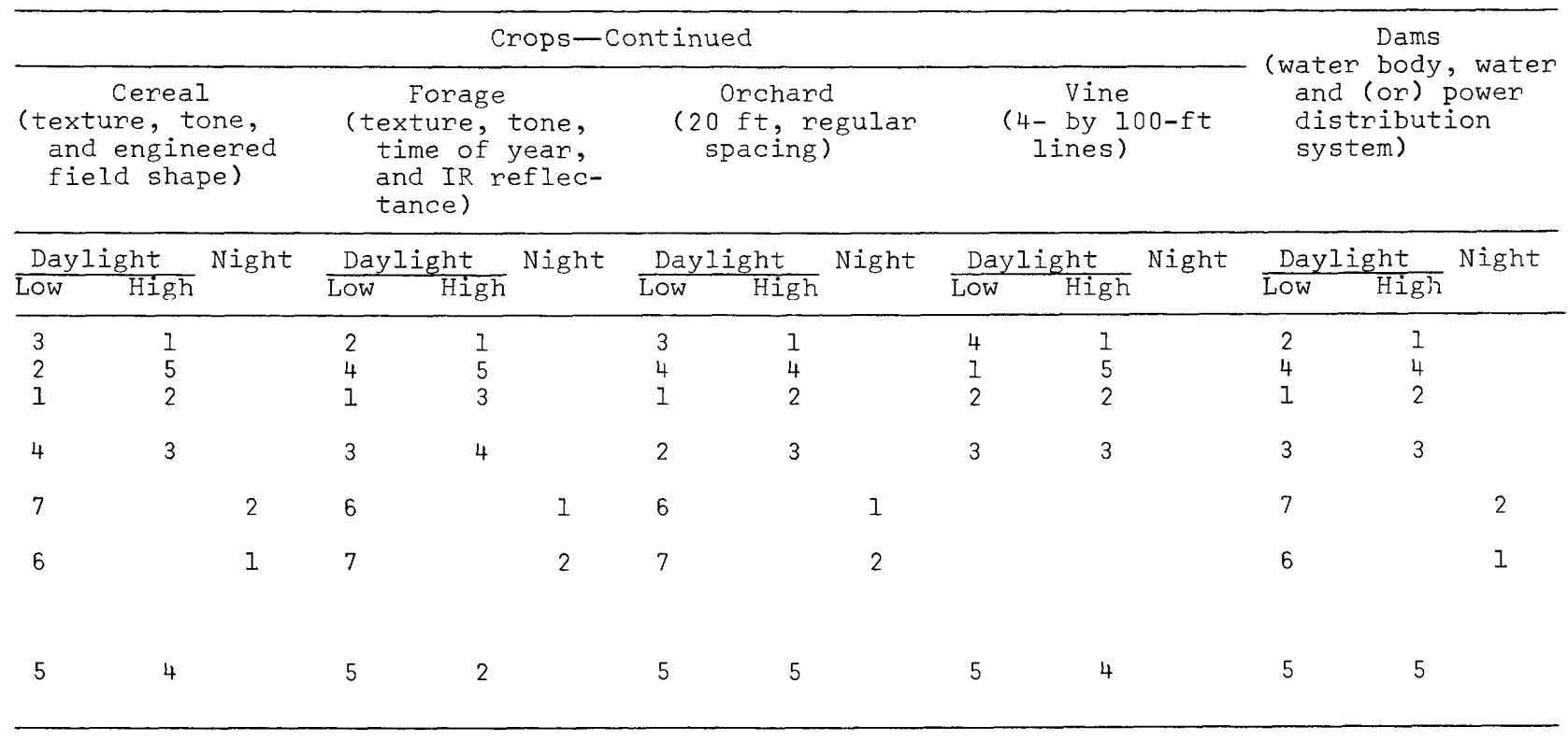




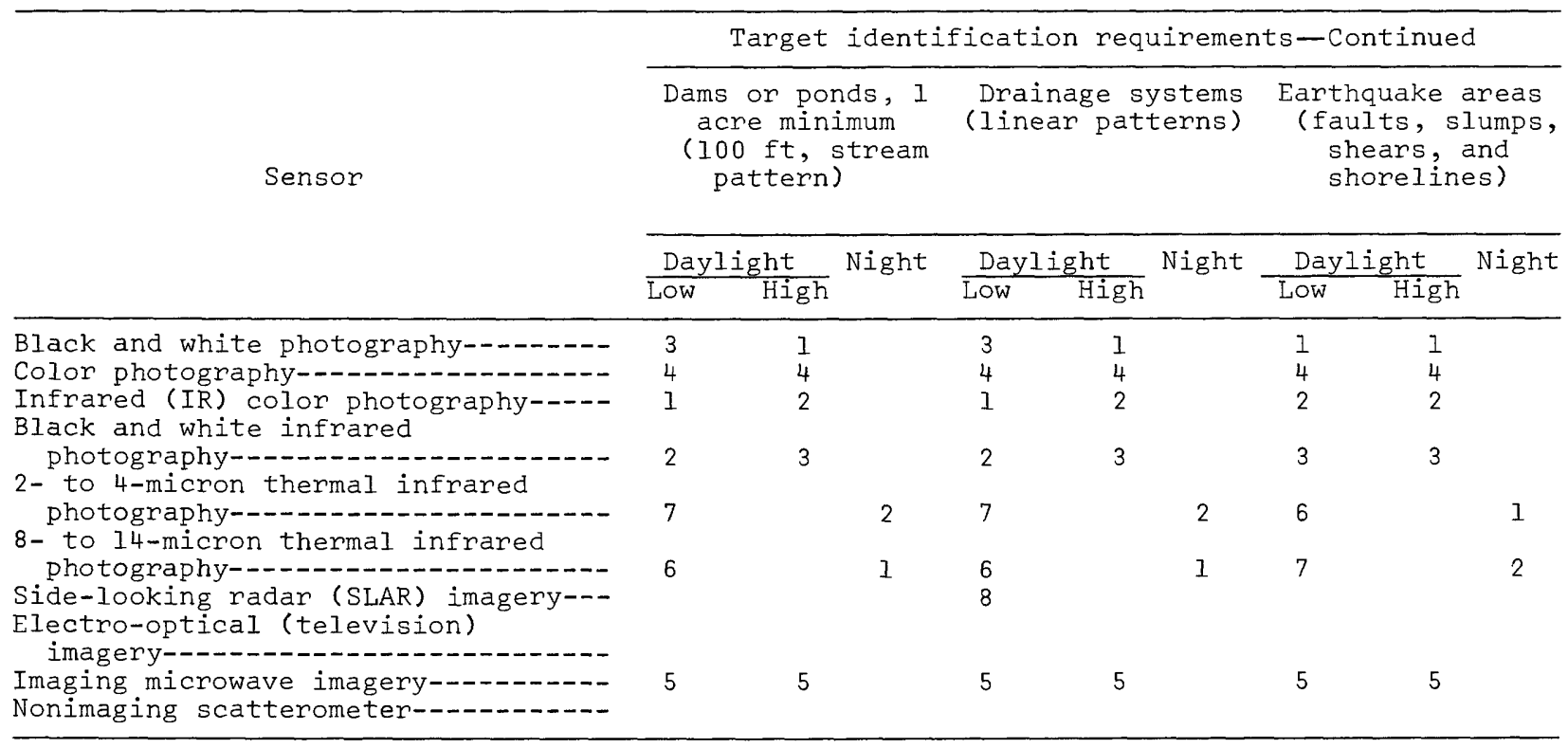

\begin{tabular}{|c|c|c|c|c|c|c|c|c|c|}
\hline \multirow{3}{*}{ Sensor } & \multicolumn{9}{|c|}{ Target identification requirements-Continued } \\
\hline & \multicolumn{3}{|c|}{$\begin{array}{c}\text { Flood areas } \\
\text { (Iimits) }\end{array}$} & \multicolumn{3}{|c|}{$\begin{array}{l}\text { Flood plains, def- } \\
\text { inition } \\
\text { (shorelines, ref- } \\
\text { use lines, re- } \\
\text { lief) }\end{array}$} & \multicolumn{3}{|c|}{ Forests } \\
\hline & \multicolumn{2}{|c|}{ Daylight } & Night & \multicolumn{2}{|c|}{ Daylight } & Night & \multicolumn{2}{|c|}{ Daylight } & Night \\
\hline Black and white photography & 3 & 1 & & 2 & 2 & & 4 & 1 & \\
\hline Color photography & 4 & 4 & & 3 & 4 & & 3 & 4 & \\
\hline $\begin{array}{l}\text { Infrared (IR) color photography--.- } \\
\text { Black and white infrared }\end{array}$ & 1 & 2 & & 4 & 3 & & 1 & 2 & \\
\hline $\begin{array}{l}\text { photography } \\
\text { 2- to 4-micron thermal infrared }\end{array}$ & 2 & 3 & & 1 & 1 & & 2 & 3 & \\
\hline $\begin{array}{l}\text { photography } \\
\text { 8- to } 14-\text { micron thermal infrared }\end{array}$ & 7 & & 2 & 7 & & 2 & 6 & & 1 \\
\hline imagery & 8 & 6 & 3 & & & & 10 & & 5 \\
\hline Imaging microwave imagery-n-_- & 5 & 5 & & 5 & 5 & & 5 & 5 & \\
\hline Nonimaging scatterometer--n----- & 9 & & & & & & 9 & & 4 \\
\hline
\end{tabular}




\begin{tabular}{|c|c|c|c|c|c|c|c|c|c|c|c|c|c|c|}
\hline \multicolumn{2}{|c|}{ Daylight } & Night & \multicolumn{2}{|c|}{ Daylight } & Night & \multicolumn{2}{|c|}{ Daylight } & Night & \multicolumn{2}{|c|}{ Daylight } & Night & \multicolumn{2}{|c|}{ Daylight } & Night \\
\hline 1 & 1 & & 1 & 1 & & 6 & 4 & & 3 & 1 & & 1 & 1 & \\
\hline 2 & 4 & & 2 & & & 4 & 1 & & 1 & 3 & & 2 & & \\
\hline 3 & 3 & & 3 & 3 & & 5 & 2 & & 2 & 2 & & 4 & & \\
\hline 4 & 5 & & 4 & 2 & & 3 & 3 & & 4 & 4 & & 3 & & \\
\hline 7 & & 2 & 6 & & 1 & 2 & & 2 & 7 & & 2 & & & \\
\hline & & & & & & 7 & 5 & 3 & & & & & & \\
\hline 5 & 2 & & 5 & 4 & & & & & 5 & 5 & & 5 & 2 & \\
\hline
\end{tabular}

\begin{tabular}{|c|c|c|c|c|c|c|c|c|c|c|c|c|c|c|}
\hline \multicolumn{9}{|c|}{ Forests-Continued } & \multicolumn{3}{|c|}{$\begin{array}{l}\text { Gross geologic } \\
\text { structure }\end{array}$} & \multicolumn{3}{|c|}{ Ice } \\
\hline Day & & Night & Das & ght & Night & Das & ght & Night & \multicolumn{2}{|c|}{ Daylight } & Night & \multicolumn{2}{|c|}{ Daylight } & Night \\
\hline 4 & 1 & & 4 & 1 & & 4 & 1 & & 2 & 1 & & 3 & 1 & \\
\hline 3 & 4 & & 3 & 4 & & 3 & 4 & & 3 & 5 & & & & \\
\hline 1 & 2 & & 1 & 2 & & 1 & 2 & & 5 & 3 & & & & \\
\hline 2 & 3 & & 2 & 3 & & 2 & 3 & & 4 & 2 & & & & \\
\hline & & & & & & & & & & & & 4 & & 1 \\
\hline 5 & 5 & & 5 & 5 & & 5 & 5 & & 6 & 4 & & & & \\
\hline 8 & & 3 & 8 & & 3 & 8 & & 3 & & & & 2 & & 2 \\
\hline
\end{tabular}

${ }^{3}$ Texture, tone, photographic IR reflectance, and season of the year. 


\begin{tabular}{|c|c|c|c|c|c|c|c|c|c|}
\hline \multirow{5}{*}{ Sensor } & \multicolumn{9}{|c|}{ Target identification requirements-Continued } \\
\hline & \multicolumn{3}{|c|}{ Ice-Continued } & \multirow{2}{*}{\multicolumn{3}{|c|}{$\begin{array}{l}\text { Irrigation networks } \\
\text { (dams, canals, } \\
\text { and agriculture } \\
\text { in an arid cli- } \\
\text { mate) }\end{array}$}} & \multirow{2}{*}{\multicolumn{3}{|c|}{$\begin{array}{c}\text { High-voltage lines } \\
\text { (poles, footers } \\
\text { clearing ac- } \\
\text { tivity, and } \\
\text { insulators) }\end{array}$}} \\
\hline & Ice & $\begin{array}{l}\text { pack dis } \\
\text { bution }\end{array}$ & stri- & & & & & & \\
\hline & \multicolumn{2}{|c|}{ Daylight } & \multirow{2}{*}{ Night } & \multicolumn{2}{|c|}{ Daylight } & \multirow{2}{*}{ Night } & \multicolumn{2}{|c|}{ Daylight } & \multirow{2}{*}{ Night } \\
\hline & Low & High & & $\overline{\mathrm{LOW}}$ & High & & $\overline{\mathrm{LOW}}$ & High & \\
\hline Black and white photography--------- & 2 & 1 & & 3 & 3 & & 1 & 1 & \\
\hline Color photography----------------- & 1 & 4 & & 4 & 4 & & 2 & $\overline{5}$ & \\
\hline $\begin{array}{l}\text { Infrared (IR) color photography----- } \\
\text { Black and white infrared }\end{array}$ & 3 & 3 & & 1 & 1 & & 3 & 2 & \\
\hline $\begin{array}{l}\text { photography---n } \\
2-\text { to } 4-m i c r o n \text { thermal infrared }\end{array}$ & 4 & 2 & & 2 & 2 & & 4 & 3 & \\
\hline $\begin{array}{l}\text { photography- } \\
\text { 8- to }-4-m i c r o n \text { thermal infrared }\end{array}$ & 7 & 7 & 2 & 7 & & 2 & 7 & & 2 \\
\hline 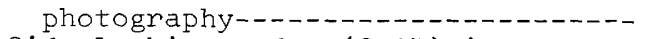 & 6 & 6 & 1 & 6 & & 1 & 8 & & 3 \\
\hline $\begin{array}{l}\text { Side-looking radar (SLAR) imagery--- } \\
\text { Electro-optical (television) }\end{array}$ & 8 & 8 & 3 & & & & 6 & & 1 \\
\hline 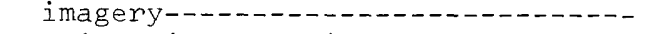 & 9 & 9 & 4 & & & & 3 & & \\
\hline $\begin{array}{l}\text { Imaging microwave imagery } \\
\text { Nonimaging scatterometer- }\end{array}$ & 5 & 5 & & 5 & 5 & & 5 & 4 & \\
\hline
\end{tabular}

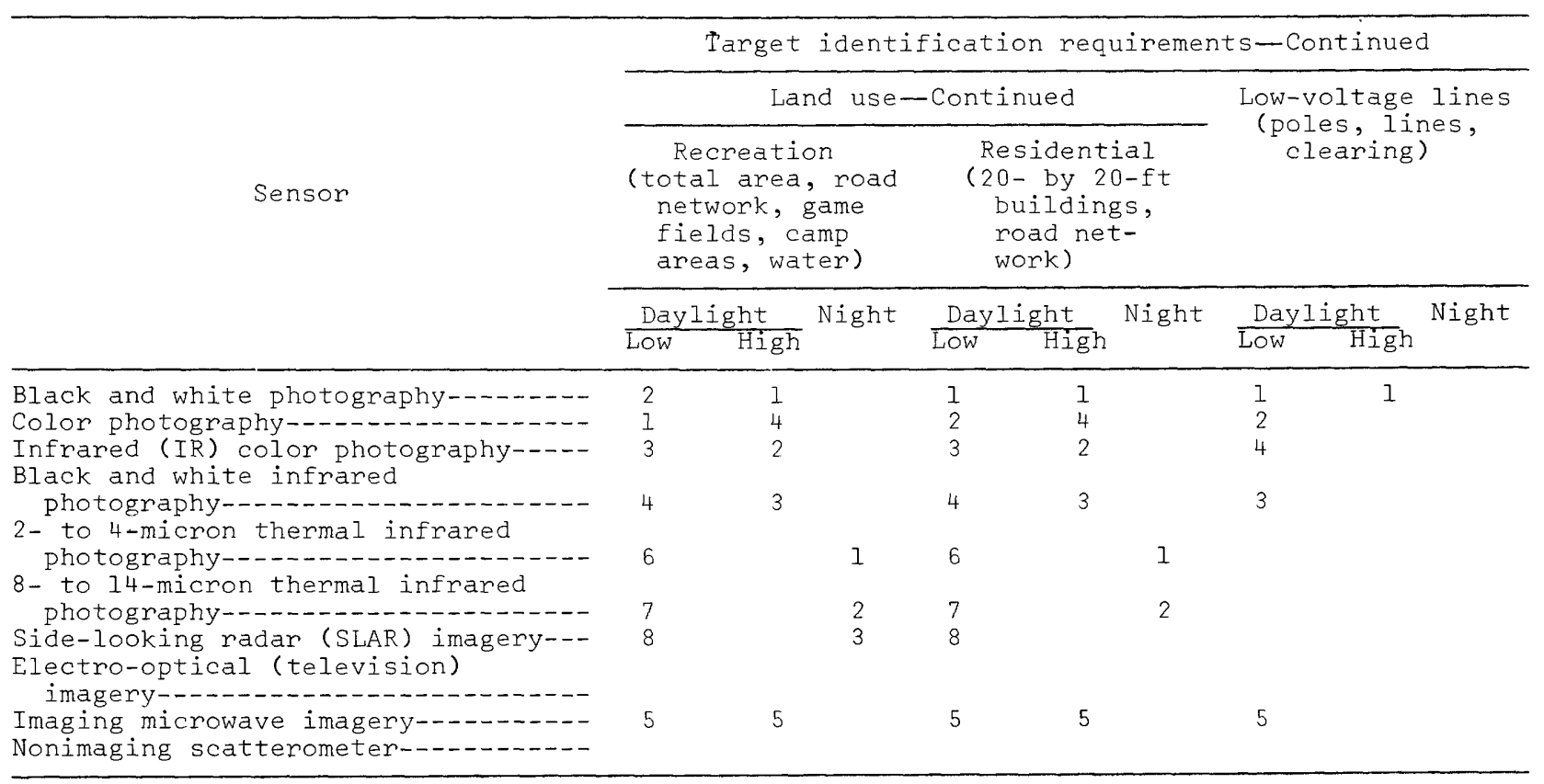




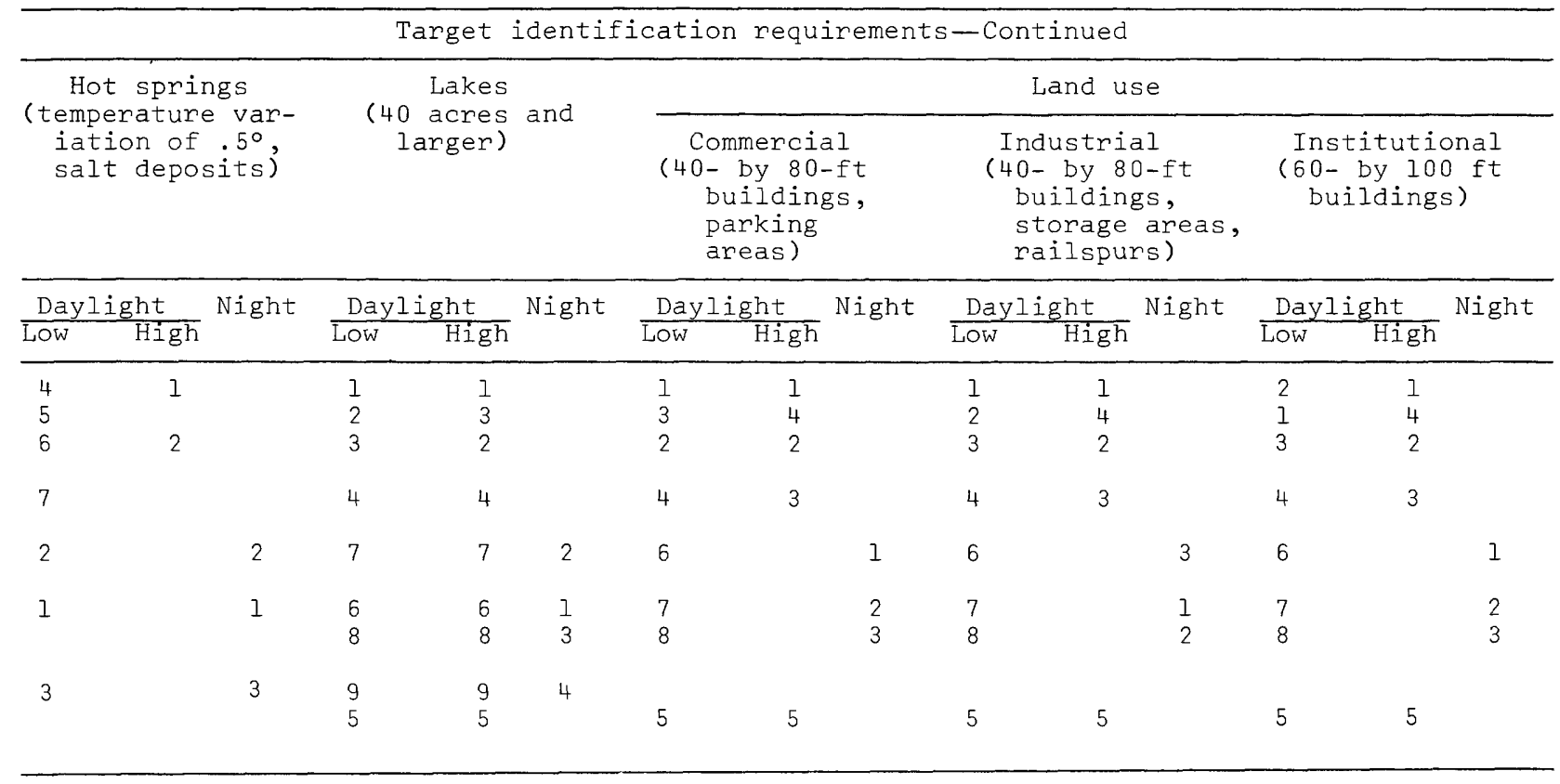

Target identification requirements-Continued

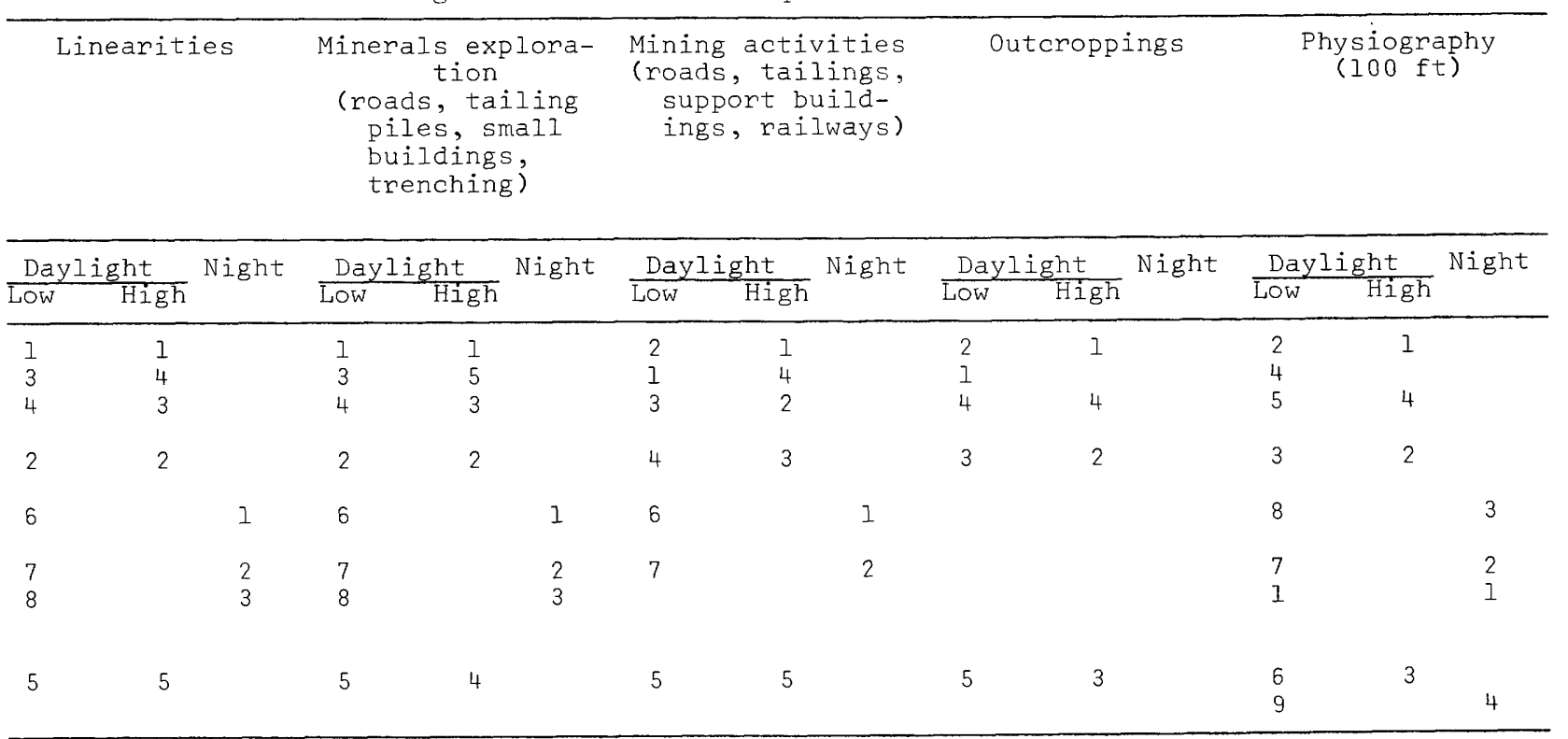




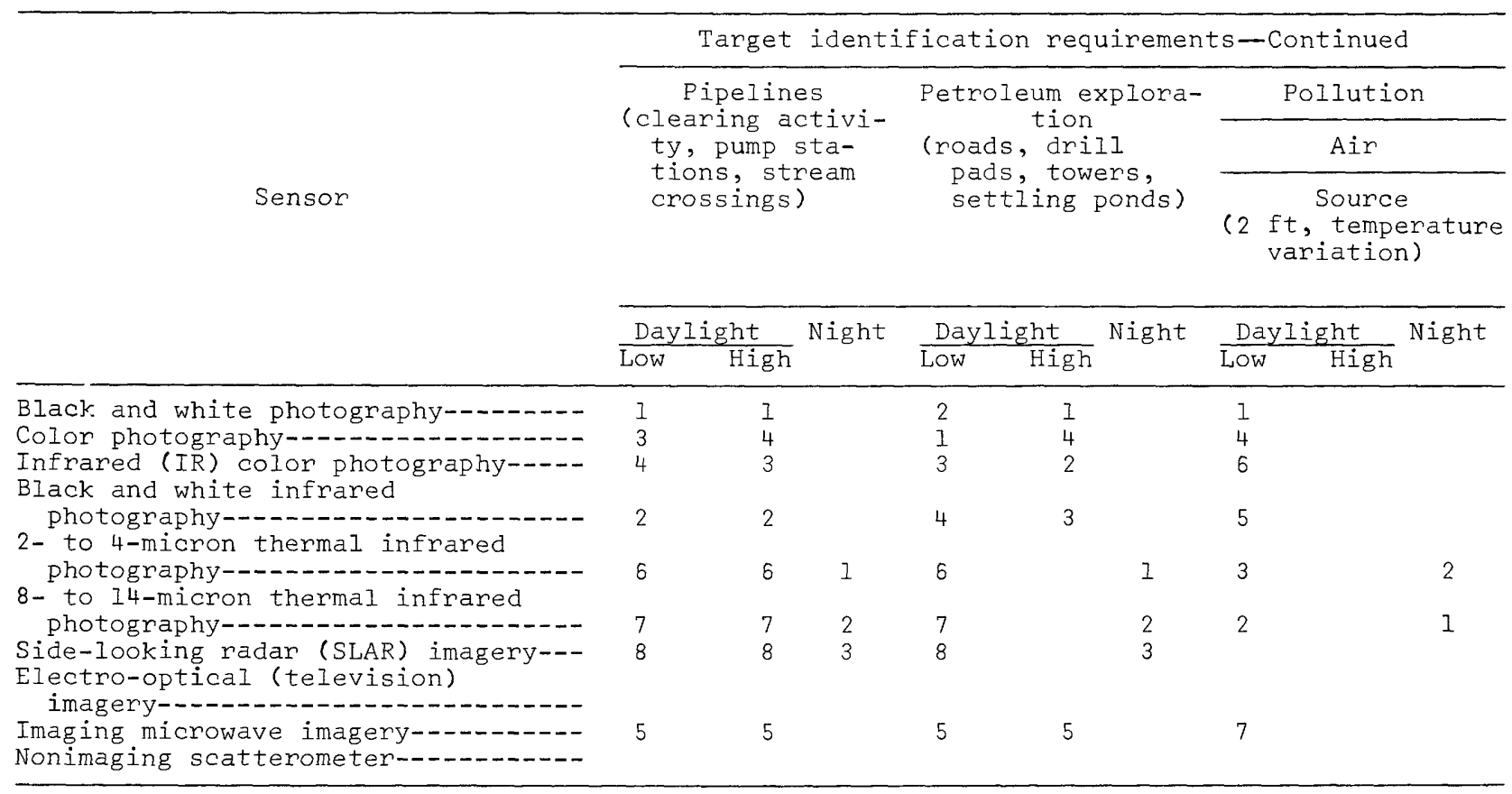

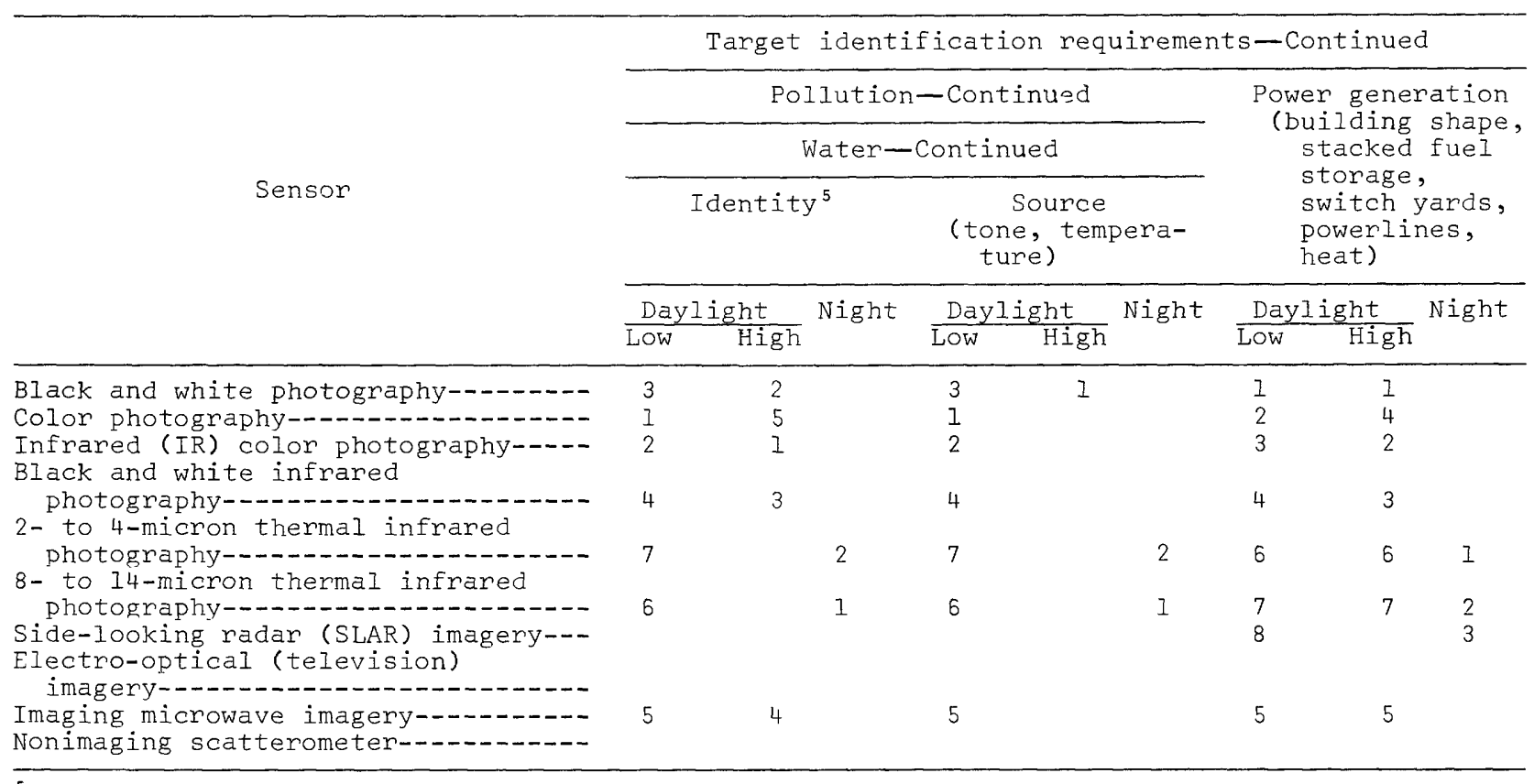

${ }^{5}$ Gross identity only; that is, chemical pollution, thermal pollution, and sedimentation. 


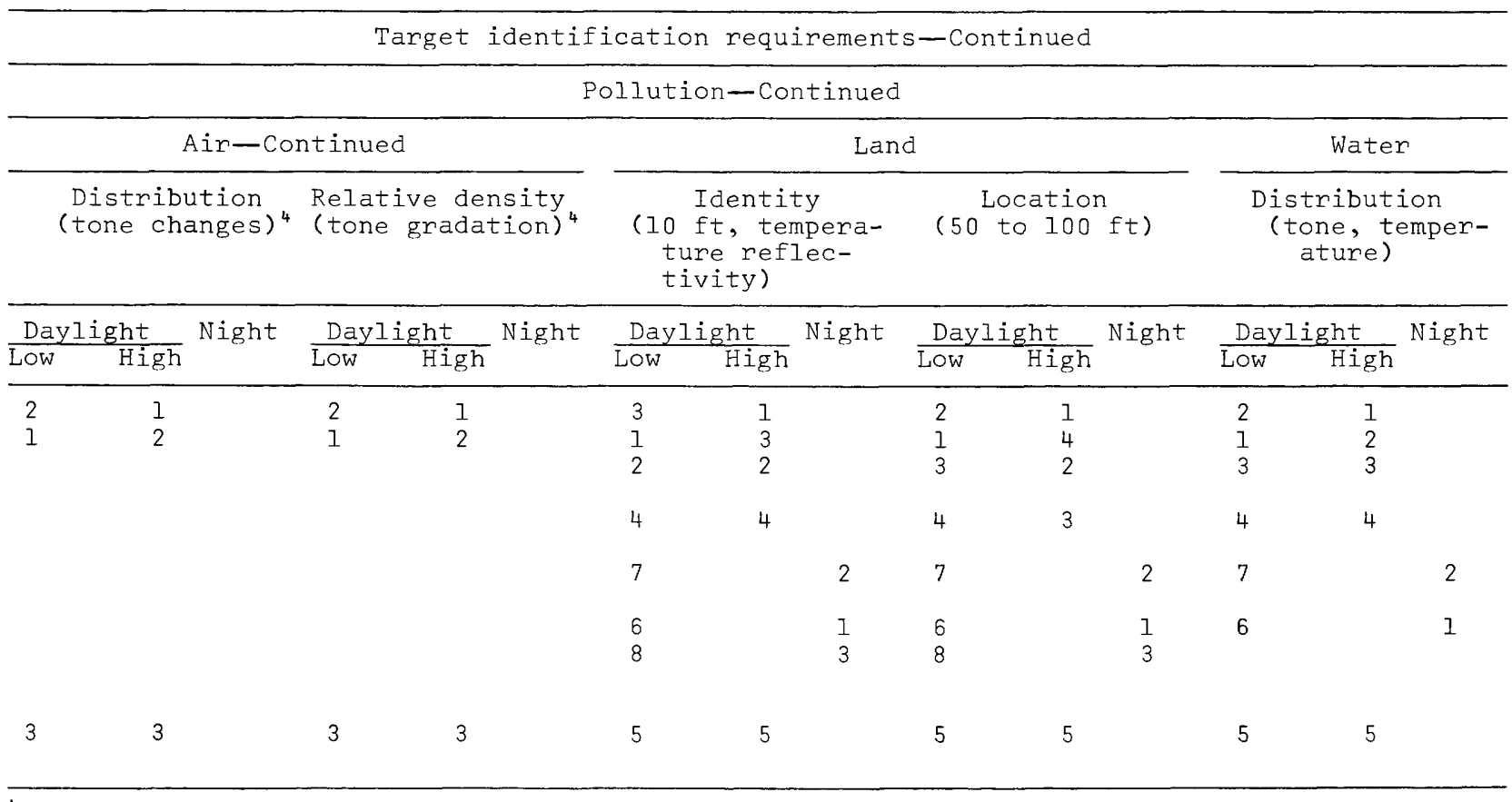

${ }^{4}$ Not an established capability.

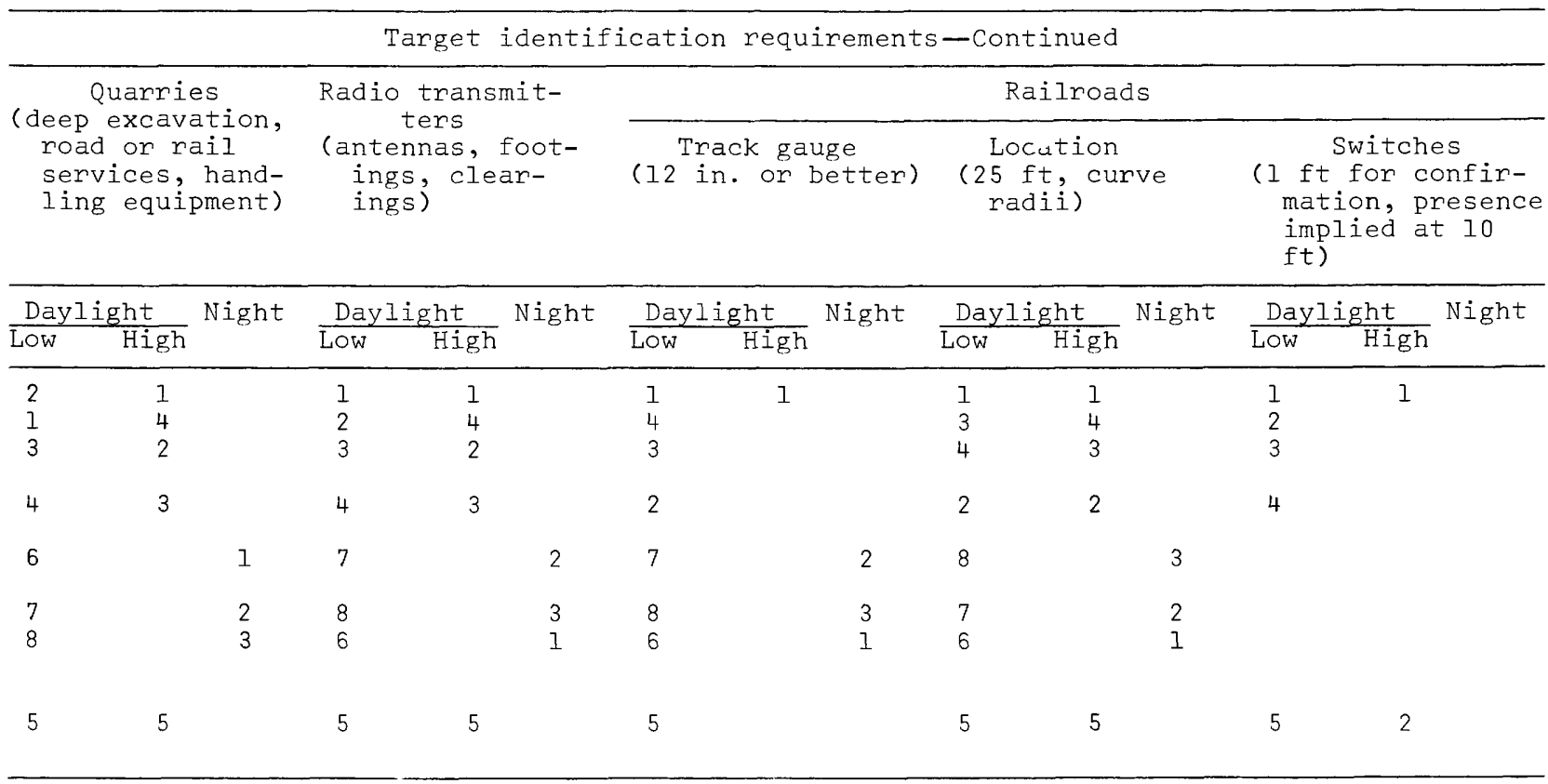




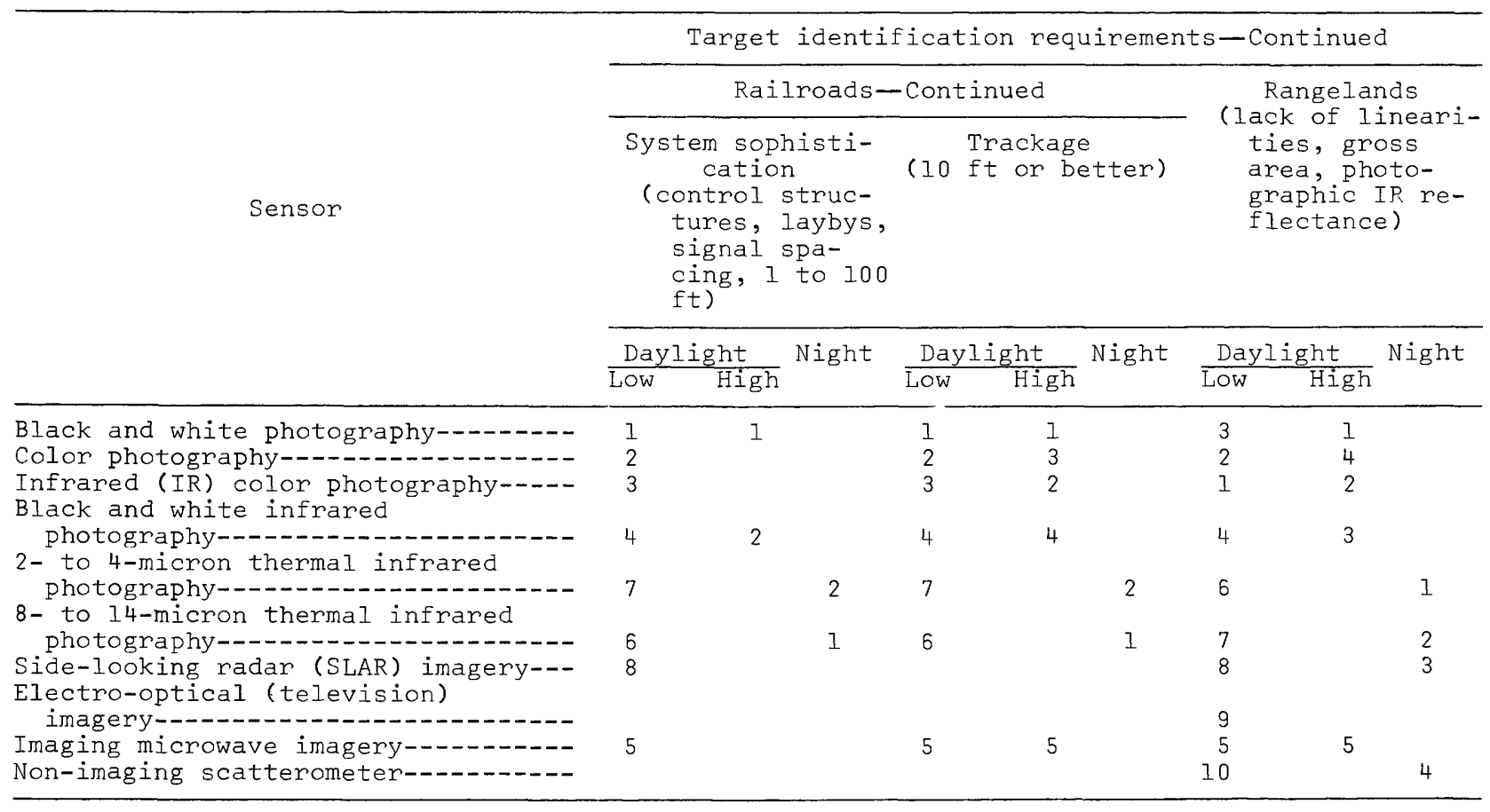

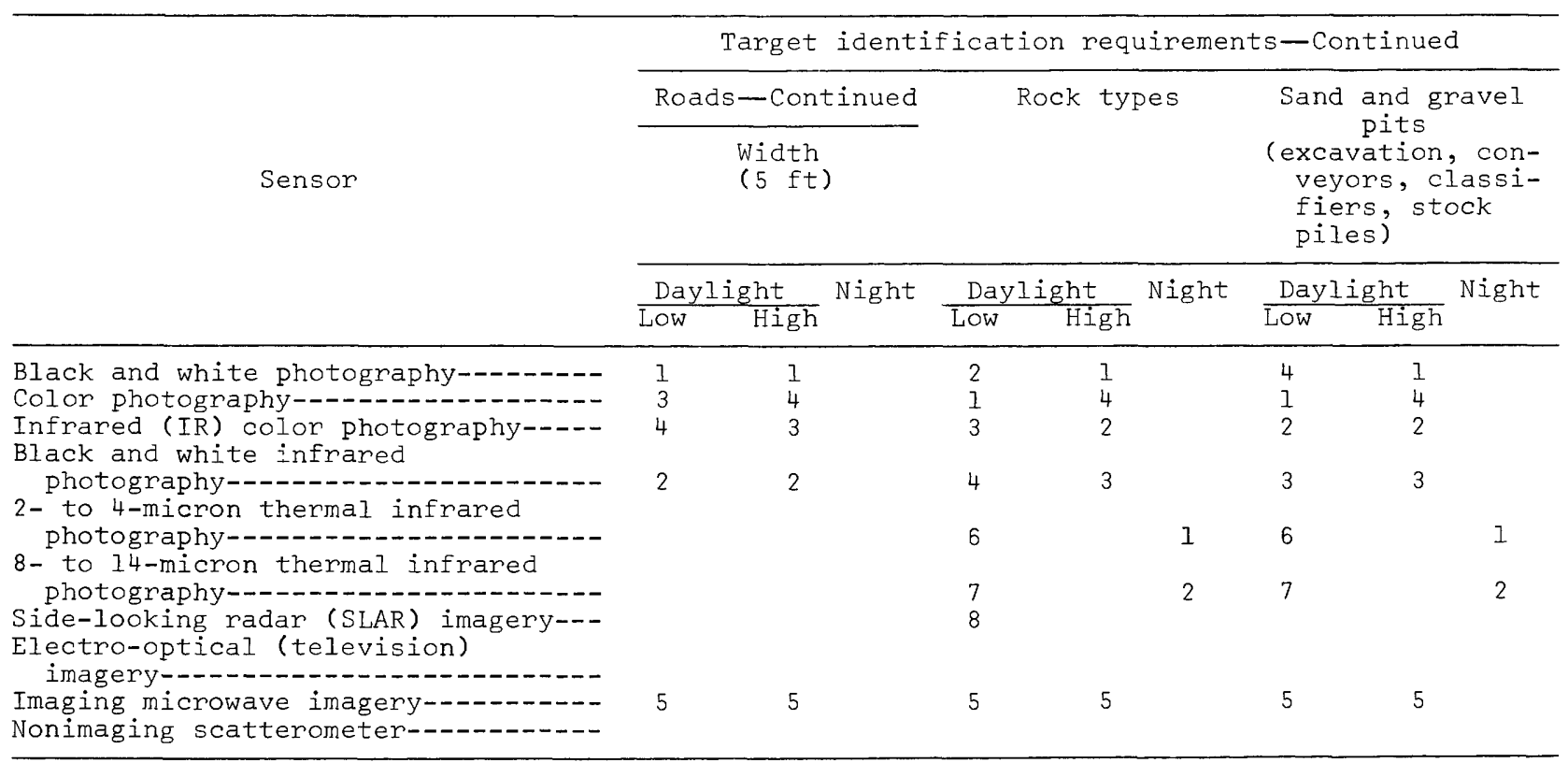


Target identification requirements-Continued

Roads

\begin{tabular}{|c|c|c|c|c|}
\hline Barriers & $\begin{array}{c}\text { Constriction } \\
(10 \mathrm{ft})\end{array}$ & Roadcuts & $\begin{array}{c}\text { Geographic loca- } \\
\text { tion } \\
(25 \mathrm{ft})\end{array}$ & $\begin{array}{c}\text { Surface material } \\
\text { (tones) }^{6}\end{array}$ \\
\hline
\end{tabular}

\begin{tabular}{|c|c|c|c|c|c|c|c|c|c|c|c|c|c|c|}
\hline \multicolumn{2}{|c|}{ Daylight } & \multirow[t]{2}{*}{ Night } & \multicolumn{2}{|c|}{ Daylight } & \multirow{2}{*}{ Night } & \multicolumn{2}{|c|}{ Daylight } & \multirow[t]{2}{*}{ Night } & \multicolumn{2}{|c|}{ Daylight } & \multirow[t]{2}{*}{ Night } & \multicolumn{2}{|c|}{ Daylight } & \multirow[t]{2}{*}{ Night } \\
\hline LOW & $\mathrm{High}$ & & Low & $\mathrm{High}$ & & LOW & High & & LOW & $\mathrm{High}$ & & Low & $\mathrm{High}$ & \\
\hline 1 & 1 & & 1 & 1 & & 3 & 1 & & 1 & 1 & & 1 & 1 & \\
\hline 3 & 2 & & 3 & 3 & & 2 & 2 & & 3 & 3 & & 4 & 4 & \\
\hline \multirow[t]{2}{*}{4} & 3 & & 4 & 2 & & 4 & 4 & & 4 & 2 & & 3 & 3 & \\
\hline & & & 7 & & 2 & 7 & & 2 & 7 & & 2 & & & \\
\hline 6 & & 1 & 8 & & 3 & & & & 6 & & 1 & & & \\
\hline 5 & 5 & & 5 & 4 & & 5 & 5 & & 5 & 5 & & 5 & 2 & \\
\hline
\end{tabular}

${ }^{6}$ Multiband and multisensor records preferred to single sensor output.

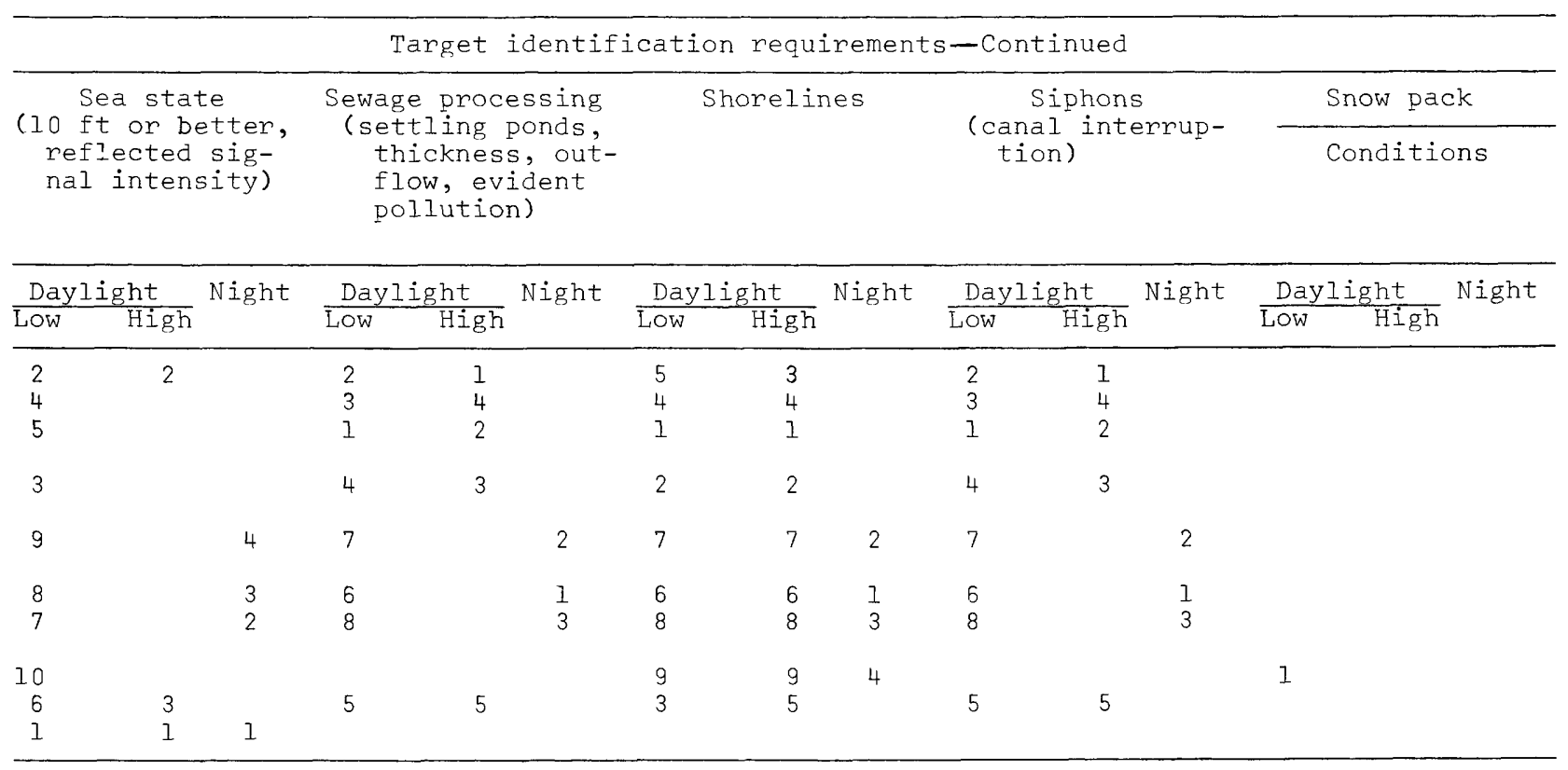




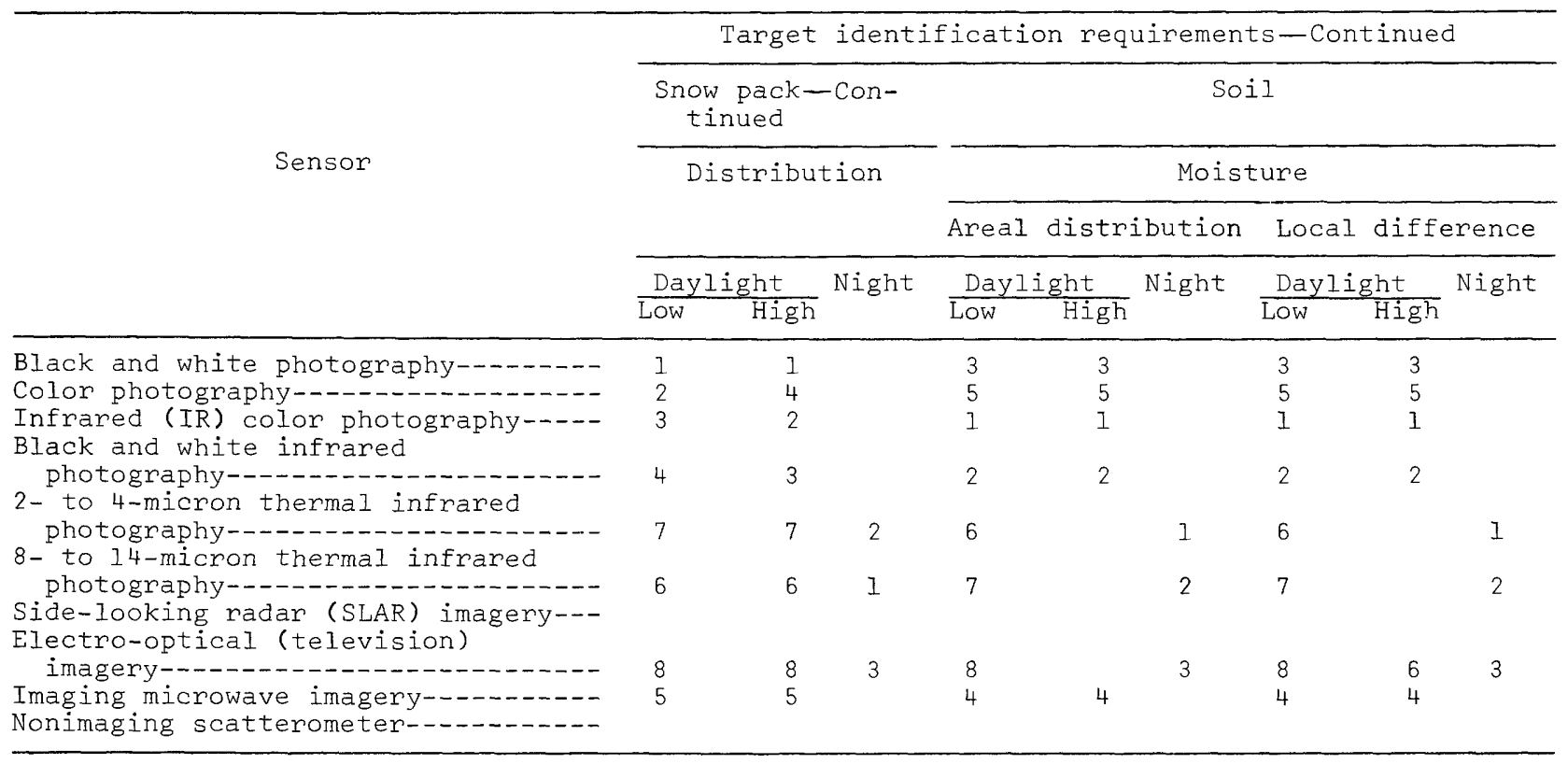

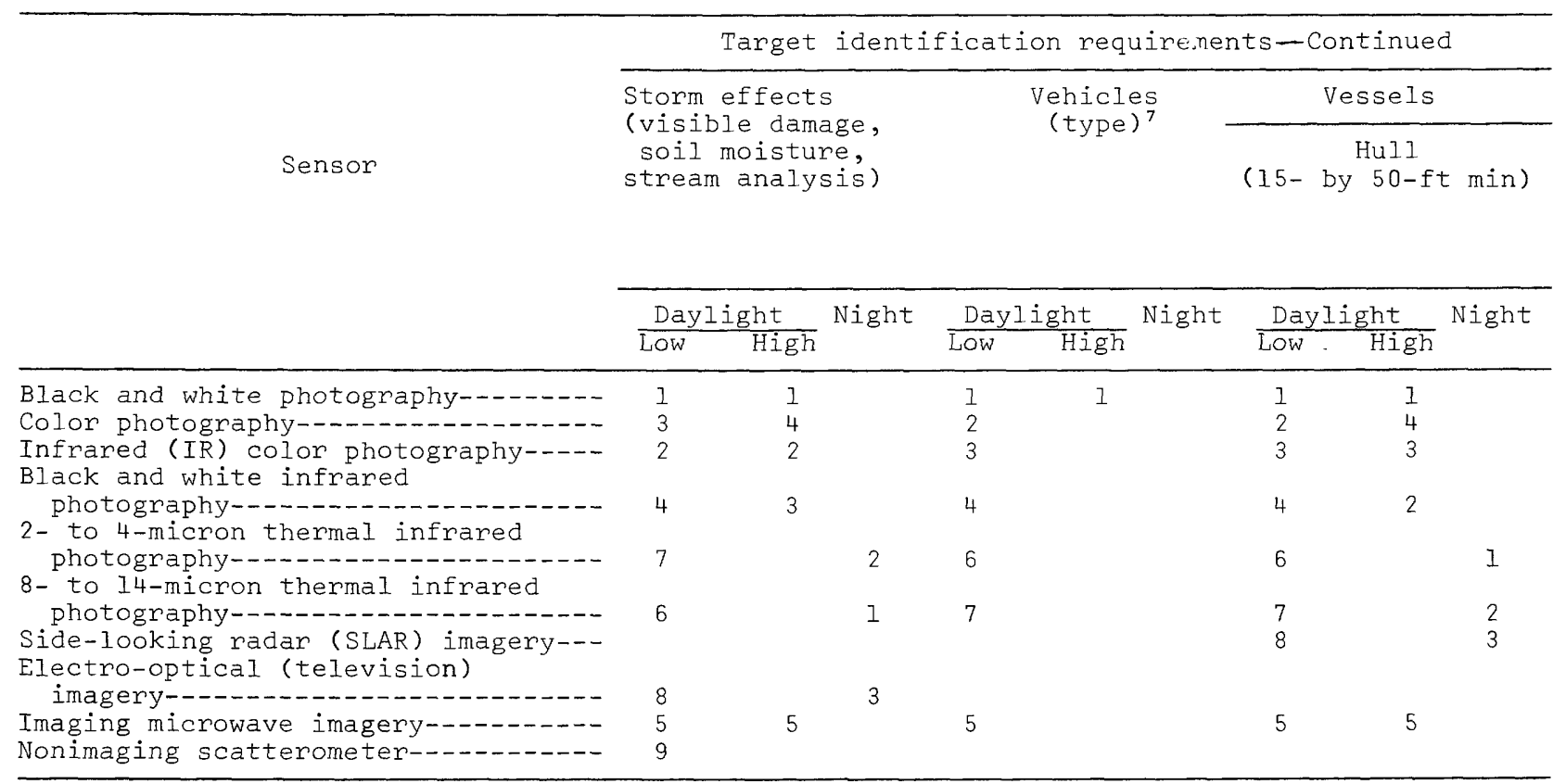

${ }^{7}$ Truck, sedan, tractor, bus, and so on. Manufacturer and year not specified. 
Target identification requirements-Continued

Soil-Continued

Stream Channels

\begin{tabular}{|c|c|c|c|c|c|c|c|c|c|c|c|c|c|c|}
\hline \multicolumn{3}{|c|}{ Texture } & \multicolumn{3}{|c|}{ Type } & \multicolumn{3}{|c|}{$\begin{array}{c}\text { Depth } \\
\text { (Water penetra- } \\
\text { tion) }\end{array}$} & \multicolumn{3}{|c|}{ Location } & \multicolumn{3}{|c|}{ Obstructions } \\
\hline \multicolumn{2}{|c|}{ Daylight } & \multirow{2}{*}{ Night } & \multicolumn{2}{|c|}{ Daylight } & \multirow[t]{2}{*}{ Night } & \multicolumn{2}{|c|}{ Daylight } & \multirow{2}{*}{ Night } & \multicolumn{2}{|c|}{ Daylight } & \multirow[t]{2}{*}{ Night } & \multicolumn{2}{|c|}{ Daylight } & \multirow{2}{*}{ Night } \\
\hline LOW & $\mathrm{High}$ & & $\overline{\mathrm{LOW}}$ & $\mathrm{High}$ & & Low & High & & Low & $\overline{\mathrm{High}}$ & & $\overline{\text { Low }}$ & High & \\
\hline 1 & 1 & & 1 & 1 & & 1 & 1 & & 3 & 1 & & 2 & 1 & \\
\hline 4 & 5 & & 4 & 5 & & 3 & 3 & & 1 & 3 & & 1 & 4 & \\
\hline 2 & 2 & & 3 & 2 & & & & & 4 & 2 & & 4 & 3 & \\
\hline 7 & & 2 & 6 & & 1 & & & & & & & & & \\
\hline
\end{tabular}

\begin{tabular}{|c|c|c|c|c|c|c|c|c|c|c|c|c|}
\hline \multirow{2}{*}{\multicolumn{2}{|c|}{ Vessels-Continued }} & \multicolumn{9}{|c|}{ Tanget identification requirements-Continued } & & \\
\hline & & \multicolumn{11}{|c|}{ Water } \\
\hline$\overline{\text { Low }} \overline{\mathrm{High}}$ & Night & Low & High & Night & LOW & High & Night & $\overline{\mathrm{LOW}}$ & High & Night & Low High & Night \\
\hline 1 & & & & & 2 & 1 & & & & & 2 & \\
\hline 4 & & & & & 1 & 4 & & & & & 4 & \\
\hline 3 & & & & & 3 & 2 & & & & & 1 & \\
\hline & & & & & 8 & 8 & 3 & 3 & 3 & 3 & & \\
\hline 5 & & & & & 5 & 5 & & & & & 5 & \\
\hline
\end{tabular}


Target identification requirements-Continued

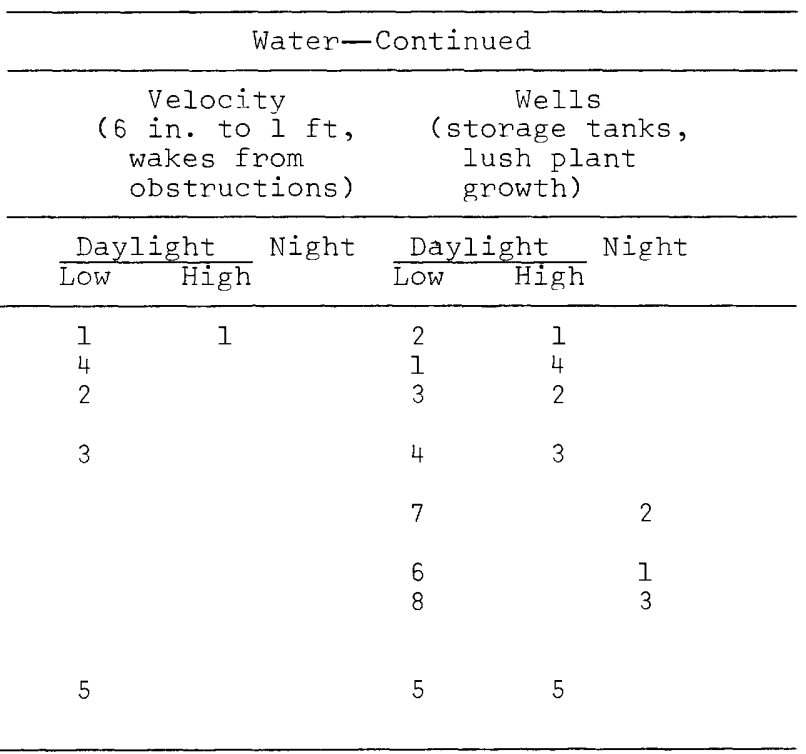

Black and white photography-.-.-.--

Color photography-----------------

Infrared (IR) color photography-----

Black and white infrared

photography--------------------

2- to 4-micron thermal infrared

photography---------------------

8- to 14-micron thermal infrared

photography---------

Side-looking radar (SLAR) imagery---

Electro-optical (television)

imagery-----------------------

Imaging microwave imagery--------

Nonimaging scatterometer------.--- 